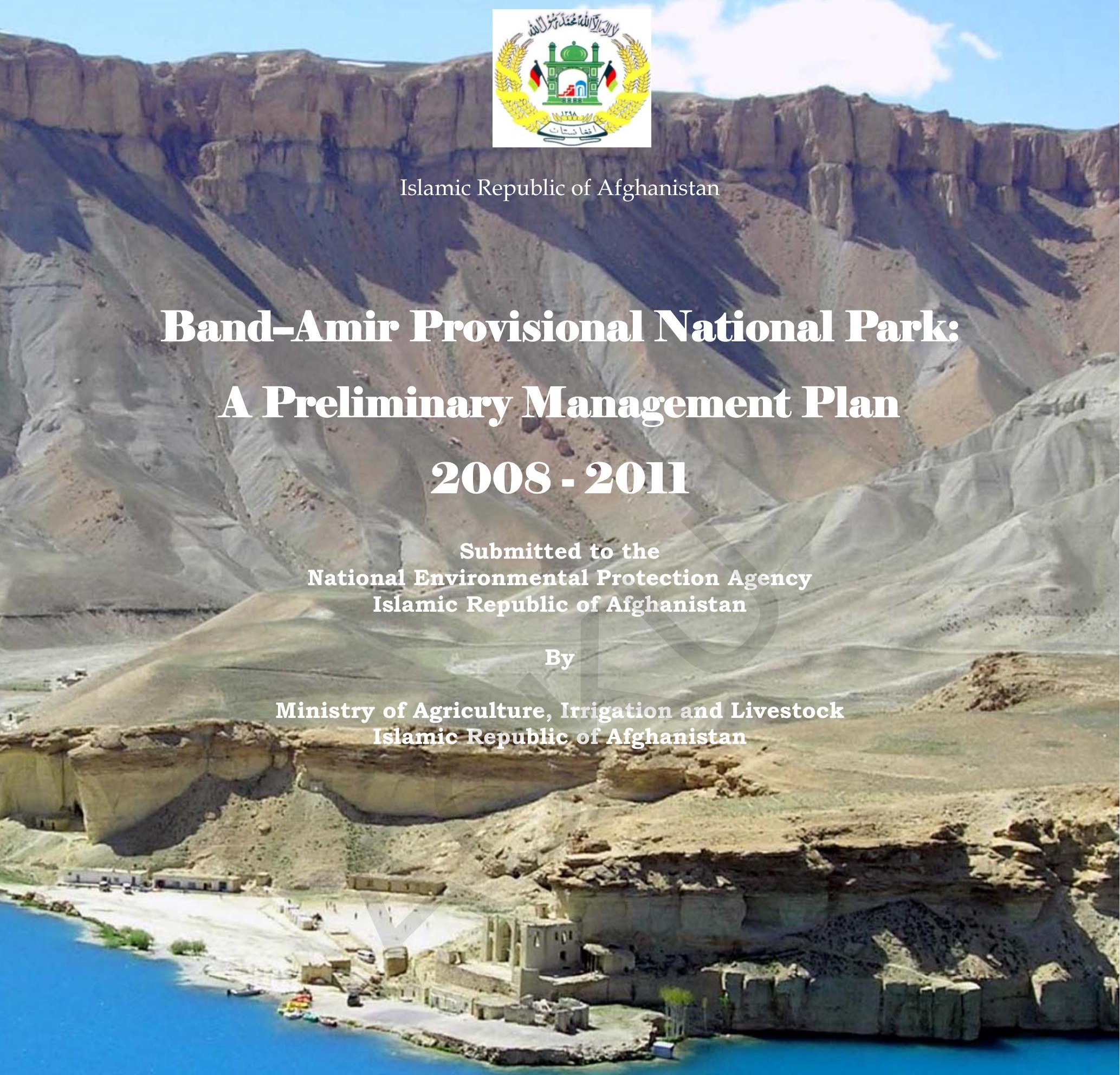

4* 


\section{Glossary of Acronyms}

$\begin{array}{ll}\text { ACC } & \text { Afghan Conservation Corps } \\ \text { ADB } & \text { Asia Development Bank } \\ \text { ATO } & \text { Afghan Tourism Organization } \\ \text { BAPAC } & \text { Band-i-Amir Protected Area Committee } \\ \text { EBA } & \text { Endemic Bird Area } \\ \text { IBA } & \text { Important Bird Area } \\ \text { IUCN } & \text { World Conservation Union } \\ \text { MoAIL } & \text { Ministry of Agriculture, Irrigation and Livestock } \\ \text { NEPA } & \text { National Environmental Protection Organization } \\ \text { NGO } & \text { Non-governmental Organization } \\ \text { NSP } & \text { National Solidarity Program } \\ \text { PRT } & \text { Provincial Reconstruction Team } \\ \text { SEA } & \text { Save the Environment Afghanistan } \\ \text { UNDP } & \text { United Nations Development Programme } \\ \text { UNEP } & \text { United Nations Environment Programme } \\ \text { UNOPS } & \text { United Nations Office for Project Services } \\ \text { UNESCO } & \text { United Nations Educational, Scientific and Cultural Organization } \\ \text { USAID } & \text { United States Agency for International Development } \\ \text { WCMC } & \text { World Conservation Monitoring Centre } \\ \text { WCS } & \text { Wildlife Conservation Society }\end{array}$




\section{Executive Summary}

The purpose of this plan is to support designation of Band-i-Amir as a Provisional National Park by the National Environmental Protection Agency (NEPA). This Preliminary Management plan provides a framework for effective interim management of Band-i-Amir for a period of three years until a complete management plan can be developed and Bandi-Amir is approved by Parliament as a full-fledged Protected Area under the provisions of the Environment Law.

The plan is based on the premise that people traditionally residing in or near Band-i-Amir will achieve an enhanced quality of life from economic benefits arising from the operations of the conservation area and will therefore conserve natural resources by limiting their land use in agreed ways necessary for maintaining the quality of Band-i-Amir's environment.

The Band-i-Amir's 6 lakes, with their crystal-clear, azure water separated by travertine dams and surrounded by spectacular red cliffs, comprise one of the world's most beautiful natural landscapes. Travertine forms when dissolved calcite $\left(\mathrm{CaCO}_{3}\right)$ precipitates out from calcium-rich spring water forming a rapidly growing "living rock".

The vegetation surrounding the lakes was originally grassland, but centuries of overgrazing, dryland farming and shrub collection has created a plant community dominated by thorn cushion plants, dwarf shrubs and poisonous weeds. The fauna of Band-i-Amir appears to be very impoverished as a result of the long history of land degradation. Band-i-Amir is considered to be a globally significant Important Bird Area (IBA). More than 84 species of birds have been identified from the area. Ibex and urial once inhabited Band-i-Amir, but their continued presence in the immediate area remains unconfirmed. Wolves, foxes, pikas and a variety of small mammals persist. The only aquatic survey at Band-i-Amir listed 37 taxa of zooplankton and 10 of zoobenthos. Only three species of fish are known to occur in the lake system.

There are 15 villages in the vicinity of Band-i-Amir lakes with a combined population of about 4,770 people. The people are ethnically Hazara and religiously Shi'a Muslim with approximately $2 / 3$ of the people identifying themselves as Sayyeds. Pashtun nomads traditionally grazed their flocks in the area during the summer, but have been excluded from Band-i-Amir for approximately 15 years. There is a rich cultural and religious tradition surrounding the lake and the 93 year-old Qadamgah Shah-i-Aulia shrine at Band-i-Haibat is a focus for pilgrims.

Land use issues revolve around irrigated farming, rain-fed farming, grazing, shrub collection, reed cutting, and waterfowl hunting. There is currently an imperfect understanding of the traditional and legal resource and land rights possessed by local people.

Band-i-Amir has been a destination for travellers since the 1950s with a peak in visits during the 1970s. Tourism was almost entirely absent during the war-years $1979-2001$. But, today Band-i-Amir is visited every year by thousands of domestic visitors and religious pilgrims as well as by many foreigners currently living and working in the country. The few visitor facilities at Band-i-Amir were centred around a haphazard and unsightly bazaar located near the shrine. This bazaar was torn down in December 2007. Recent initiatives have been the construction of a visitor centre, toilets, entry kiosk, parking lot, and bathing shelters.

This plan proposes that Band-i-Amir be designated as a National Park. The vision for Band-i-Amir National Park is: 
Vibrant, healthy communities living in harmony with, and engaged in maintaining, an intact lake system, an environment rich in natural beauty, pure water and wildlife that provides high-quality visitor experiences.

The following broad goals are intended to achieve this vision:

1. Preserve the integrity of Band-i-Amir's travertine dams and lakes;

2. Improve livelihoods in communities near Band-i-Amir;

3. Conserve and recover the biodiversity and ecosystem integrity of Band-i-Amir;

4. Provide opportunities for quality recreational, cultural and religious experiences for Afghan citizens and international travellers; and

5. Ensure that local communities are actively engaged in development and management of Band-i-Amir.

Fifteen objectives will be addressed in the next three years through undertaking 29 specific actions.

Programs are described to address resource use, growth management, visitor use, facilities and commercial operations, conservation awareness, research and planning, and community development. Operational issues treated include boundaries and zoning, prohibited activities and fines, entry fees, budgets, and community participation.

Appended to the document is a Collaborative Management Agreement in the form of a contract between the Band-i-Amir Protected Area Committee (BAPAC), the Ministry of Agriculture, Irrigation and Livestock (MoAIL) and Band-i-Amir communities. This contract formalizes rights and responsibilities of all parties and specifies how revenues will be shared among the parties. Also attached are the Rules of Procedure governing operations and decision-making by the BAPAC. 


\section{Acknowledgements}

This paper was prepared by Christopher Shank of the USAID-funded Afghanistan Biodiversity Conservation Program implemented by the Wildlife Conservation Society. He was helped immeasurably by the Band-i-Amir Coordinating Committee, the Band-i-Amir Protected Area Committee and individual members of Band-i-Amir communities.

Khushal Habibi provided numerous interpretations, clarifications and corrections. Comments on the manuscript were made by Kara Stevens, Wali Modeqeq, Peter Zahler, Ayub Alavi, McKenzie Johnson and Kareem Merchant. Jim Wingard and Belinda Bowling helped with the Collaborative Management Agreement and advised on various legal aspects. 


\section{TABLE OF CONTENTS}

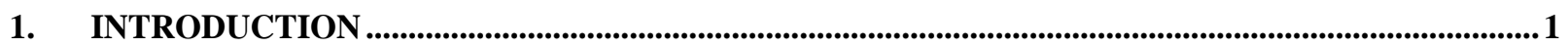

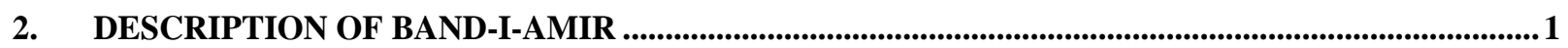

3. LEGAL STATUS AND HISTORY OF ESTABLISHMENT.....................................................................

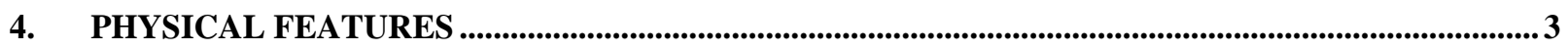

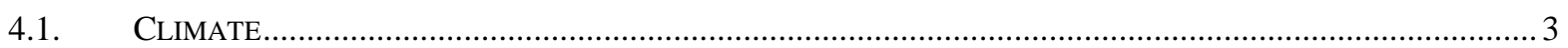

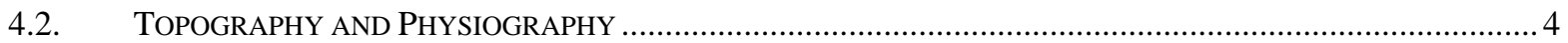

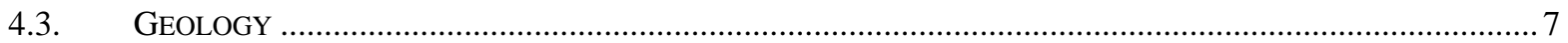

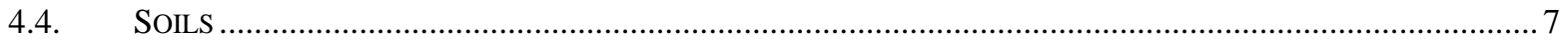

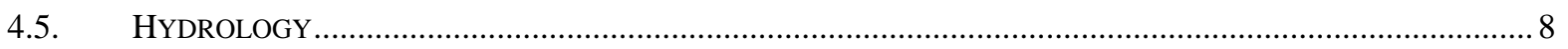

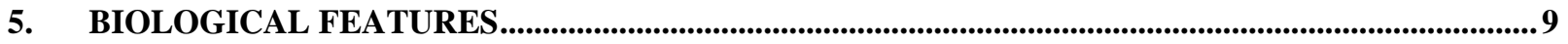

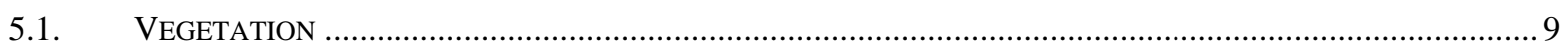

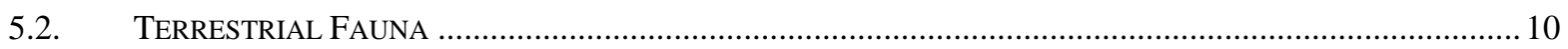

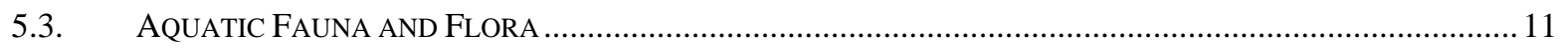

6. HUMAN POPULATION AND LAND-USE ........................................................................................... 12

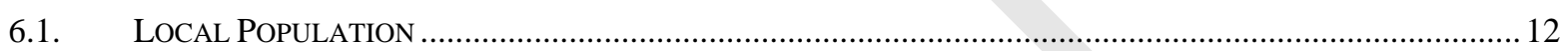

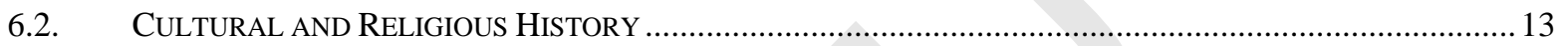

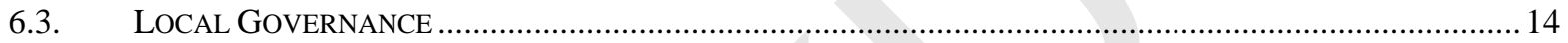

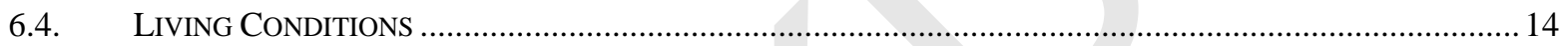

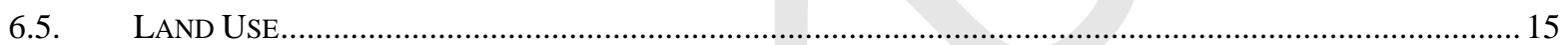

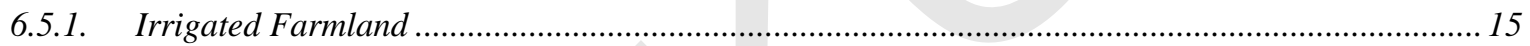

6.5.2. Dryland Farming ………………………………………………………………………. 15

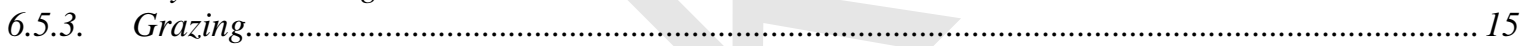

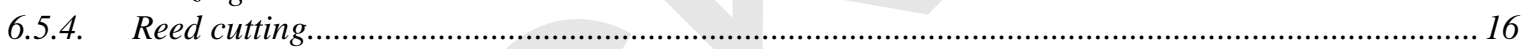

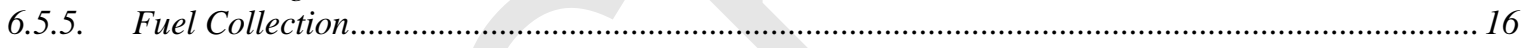

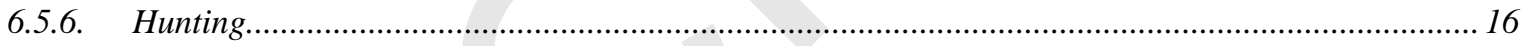

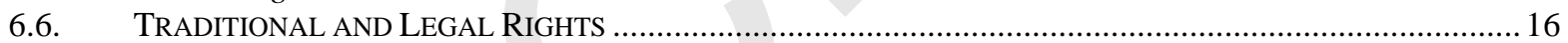

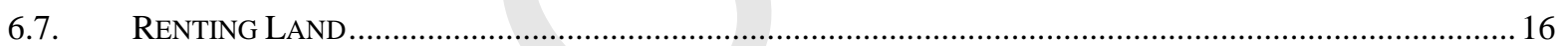

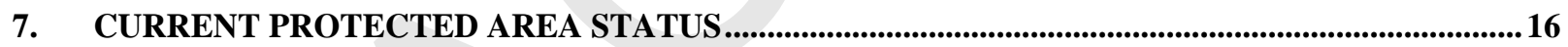

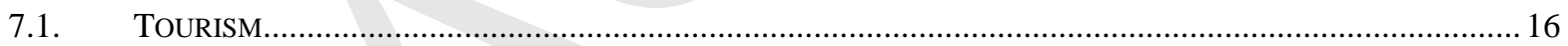

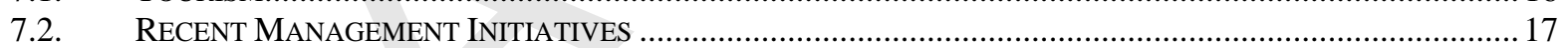

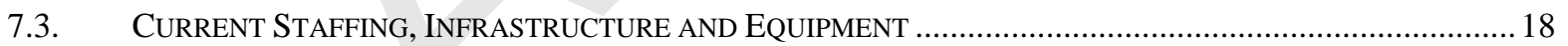

7.4. CURRENT THREATS TO THE ENVIRONMENT ………..................................................................... 18

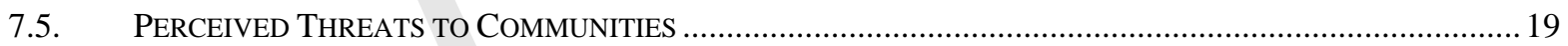

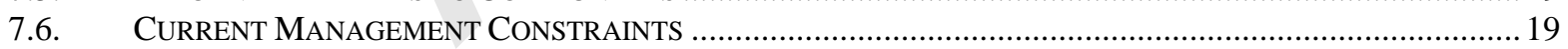

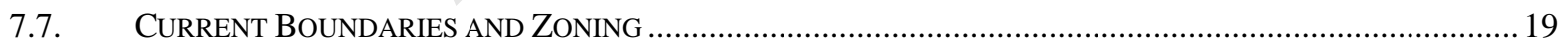

8. MANAGEMENT PRESCRIPTION ...................................................................................................19

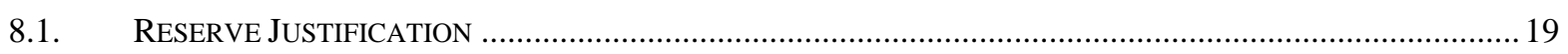

8.1.1. Addressing Objectives of the National Protected Area System ........................................................ 20

8.1.2. Advantages of Band-i-Amir as a Protected Area .......................................................................... 20

8.1.3. Disadvantages of Band-i-Amir as a Protected Area ........................................................................ 20

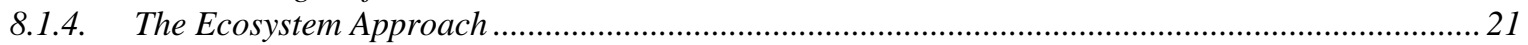

8.1.5. Harmonization with national and provincial approaches..............................................................22

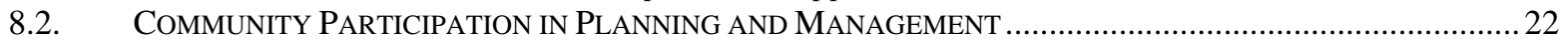

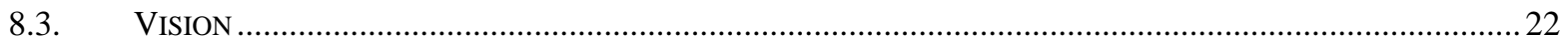

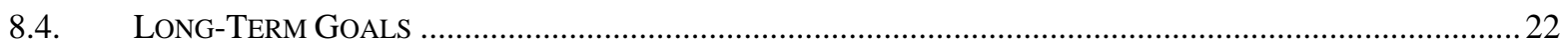

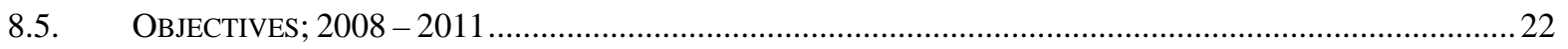

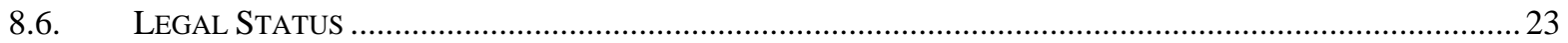

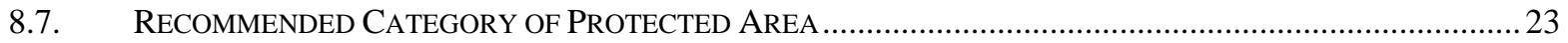

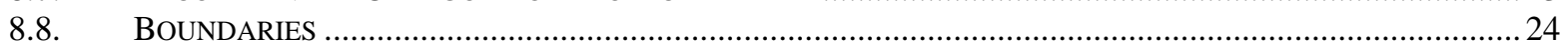

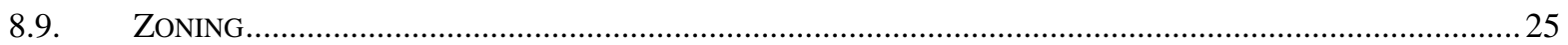

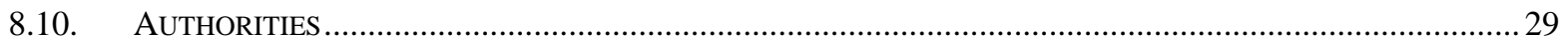


8.10.1. Band-i-Amir Protected Area Committee .............................................................................. 29

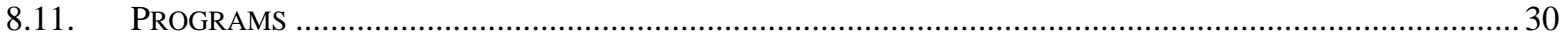

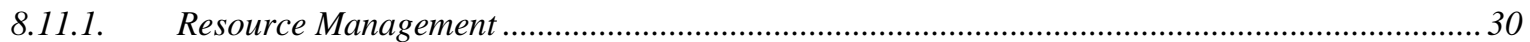

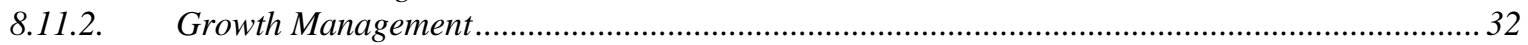

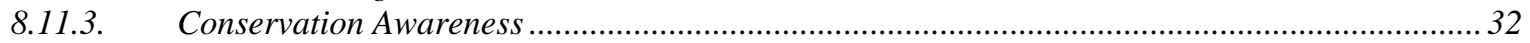

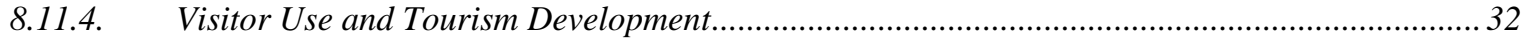

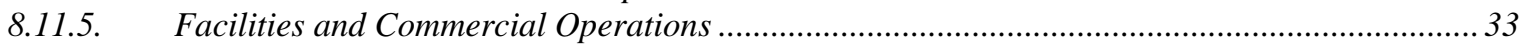

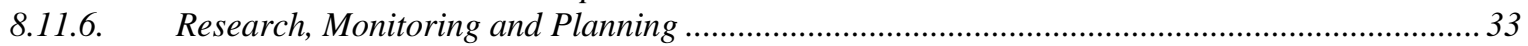

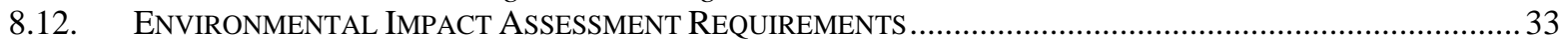

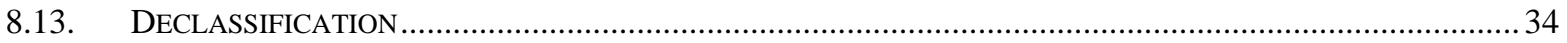

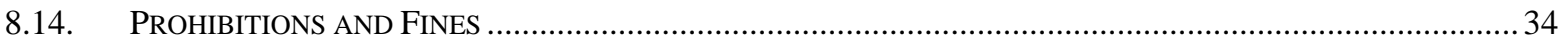

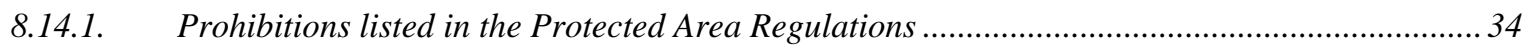

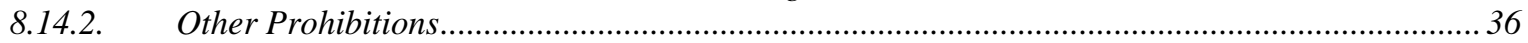

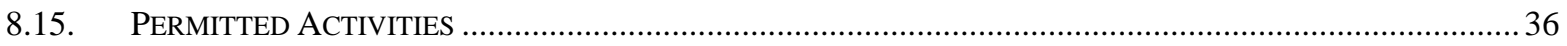

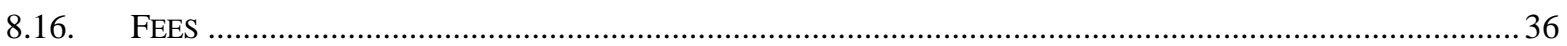

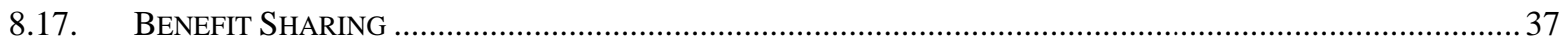

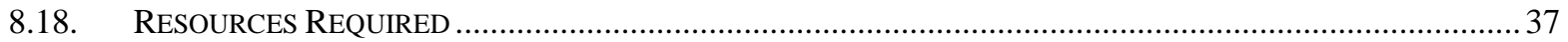

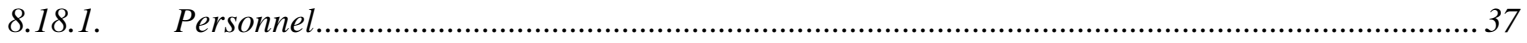

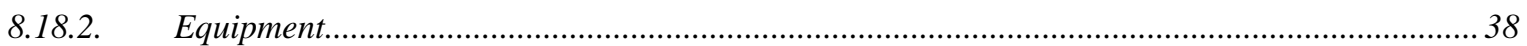

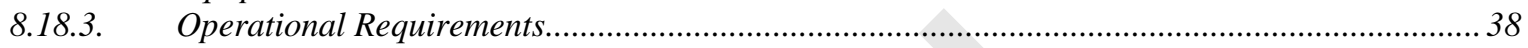

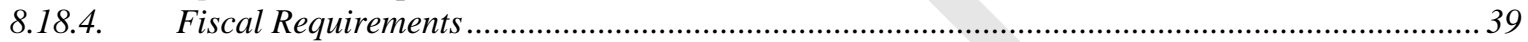

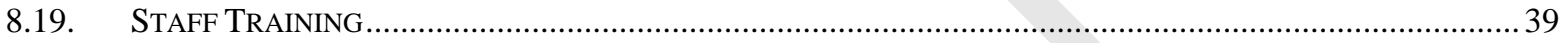

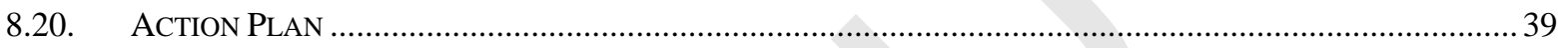

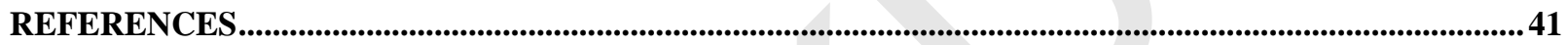

APPENDIX 1. COLLABORATIVE MANAGEMENT AGREEMENT: BAND-I-AMIR

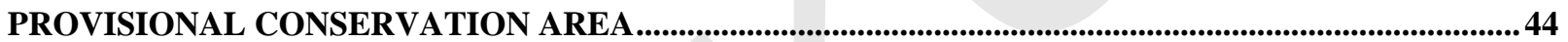

APPENDIX 2. RULES OF PROCEDURE, BAND-I-AMIR COORDINATING COMMITTEE ..................49

APPENDIX 3. RECOMMENDATIONS TO THE MINISTRY OF JUSTICE ON PENALTIES FOR VIOLATION OF THE REGULATIONS AND PROHIBITIONS.

\section{Tables}

Table 1. Monthly mean, maximum and minimum temperatures $\left(\mathrm{C}^{\circ}\right)$ at Jarukushan during summer 2007. ................................................................................ 4

Table 2. Size, depth and volume of Band-i-Amir lakes................................... 8

Table 3. Physical and chemical properties of waters in Band-i-Amir Lakes (from Pradhan 2006).

Table 4. Birds contributing to Band-i-Amir being listed as an internationally Important Bird Area (IBA) by BirdLife International. ................................................ 10

Table 5. Villages in the Band-i-Amir area (ADB 2006) . .................................. 12

Table 6. Objectives of different IUCN categories of protected areas (from IUCN 1994). . 23

Table 7. Areas of Band-i-Amir management zones. ....................................... 26

Table 8. Research needs for Band-i-Amir National Park. .Error! Bookmark not defined.

Table 9. Summary of permitted and restricted activities in Band-i-Amir management

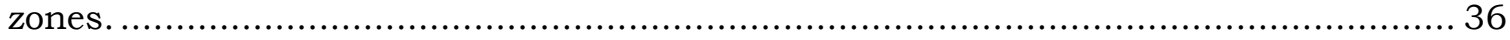

Table 10. Staff positions needed for Band-i-Amir National Park. .......................... 37

Table 11. Equipment list for Band-i-Amir National Park. ..................................... 38

Table 12. Operational funding needed to run Band-i-Amir National Park................. 38

Table 13. Total funding requirements for Band-i-Amir for the next three years. ......... 39

Table 14. Action Plan for implementation of Band-i-Amir National Park over the next 3 years. 


\section{Figures}

Figure 1. Location of Band-i-Amir National Park in Bamiyan Province and in Afghanistan.

Figure 2. Monthly mean max/min temperature and precipitation at Bamiyan. Data from

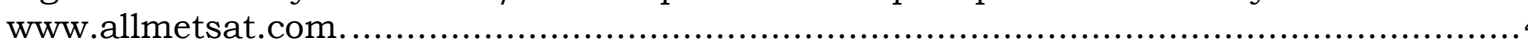

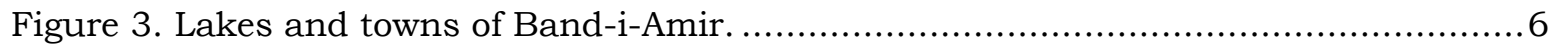

Figure 4. The ecosystem approach at Band-i-Amir............................................. 21

Figure 5. Boundaries and management zones of Band-i-Amir Nationa Park.................22

Figure 6. Strict Protection and Amenities Zones around Band-i-Amir Lakes...................28

Figure 7. Buffer Zone for Band-i-Amir National Park............................................... 31 


\section{Introduction}

The purpose of this plan is to support designation of Band-i-Amir as a Provisional Conservation Area by the National Environmental Protection Agency (NEPA) of the Protected Areas Regulations. The Protected Area Regulations state that a Provisional Conservation Area shall be administered by a Preliminary Management Plan. This Preliminary Management Plan provides a framework for effective interim management of Band-i-Amir until a complete management plan can be developed and Band-i-Amir is approved by Parliament as a full-fledged Protected Area under §of the Environment Law. The intended life of this plan is three years following approval.

This plan is explicitly based on the premise that people traditionally residing in or near Band-i-Amir will achieve an enhanced quality of life from economic benefits arising from the operations of the conservation area and will therefore conserve natural resources by limiting their land use in agreed ways necessary for maintaining the quality of Band-iAmir's environment.

This plan addresses all issues required of a management plan under the Protected Area Regulations. The plan may be amended as necessary by majority vote of a quorum of the Band-i-Amir Protected Area Committee (BAPAC).

\section{Description of Band-i-Amir}

Band-i-Amir lakes, with their crystal-clear, azure water separated by travertine dams and surrounded by spectacular red cliffs, comprise one of the world's most uniquely beautiful natural landscapes. Band-i-Amir ${ }^{1}$ is located in the western Hindu Kush in the Yakowlang District of Bamiyan Province. It lies about $185 \mathrm{~km}$ north-northwest of Kabul and $55 \mathrm{~km}$ west of Bamiyan town (Figure 1). It is accessed via Yakowlang or a direct road from Bamiyan town. Road access to Band-i-Amir is restricted from December to late April due to snow. The Band-i-Amir lakes are located in an east-west trending valley at approximately $2,900 \mathrm{~m}$ elevation. The travertine dams separating the lakes form when calcite precipitates out from calcium-rich groundwater welling up from underwater springs. The lakes are bounded by sheer limestone cliffs topped by a high plateau.

The individual lakes (Figure 3) differ markedly in character. Band-i-Gholaman is shallow, has extensive reedbeds and is commonly used by waterfowl. Band-i-Qanbar is filled only seasonally and forms a large, wet marshy area. Band-i-Haibat has deep waters and a narrow, vertical-sided travertine dam on the eastern end. The dam on Band-i-Panir has a broad, smooth and undulating creamy-white surface. Band-i-Pudina is small and surrounded by a labyrinth of small, interconnected potholes, streams and dense vegetation. Band-i-Zulfiqar is large, deep and surrounded by steep cliffs virtually devoid of vegetation.

\footnotetext{
${ }^{1}$ The Dari term band refers to either a dam or the water reservoir held behind a dam.
} 


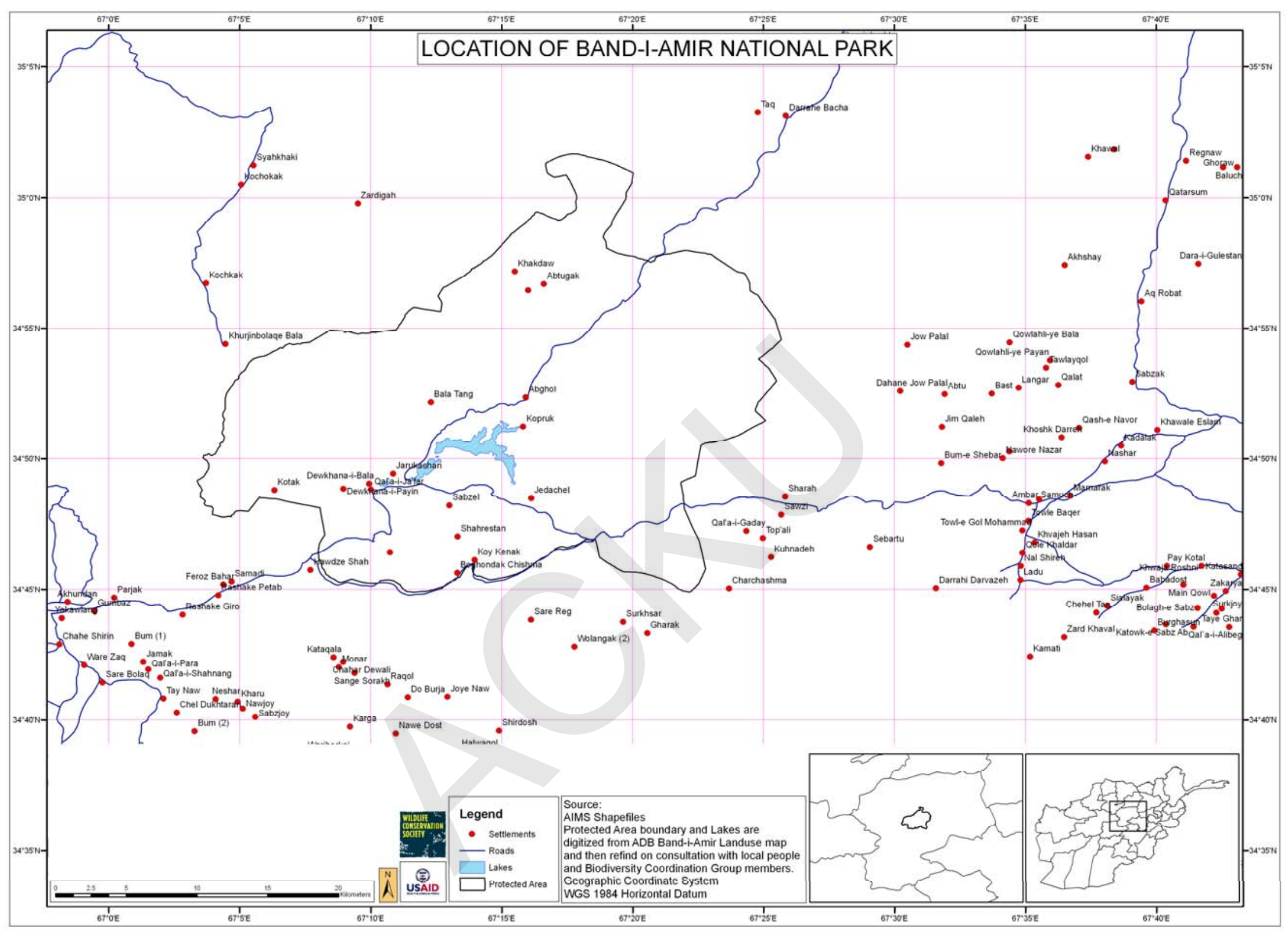

Figure 1. Location of Band-i-Amir National Park in Bamiyan Province and in Afghanistan. 


\section{Legal Status and History of Establishment}

The Afghan Tourist Organization (ATO) has long recognized the tourism potential of Band-i-Amir and, on September 30, 1973 (8 Mezan 1352), petitioned the national government to declare the area a national park. However, this declaration was not published in the official government Gazette by the Ministry of Justice. Therefore, Band-i-Amir has never enjoyed legal status (Sayer and van der Zon 1981). Band-i-Amir remained under the de facto control of the ATO until the late 1970s, although the Directorate of National Parks and Wildlife in the Ministry of Agriculture expressed willingness to assume responsibility for its management (Shank and Larrson 1977).

Despite not being legally established, Band-i-Amir does appear on UNEP-WCMC's World Database on Protected Areas as an IUCN Category II protected area (i.e., a national park). However, the database indicates that there is currently no active management.

FAO (Shank and Larrson 1977) developed a strategy for the establishment of Band-iAmir National Park comprised of a biophysical and social inventory, proposed boundaries, and a legal and planning strategy. The advent of war made it impossible to develop the preliminary plan any further.

Band-i-Amir is currently on the UNESCO World Heritage Convention Tentative List of World Heritage Sites based on a submission by the Ministry of Irrigation, Water Resources and Environment and Ministry of Agriculture on 8 September 2004 (18 Aqrab 1383) (http://whc.unesco.org/en/tentativelists/1946/).

\section{Physical Features}

\subsection{Climate}

There is very little climatic information for Band-i-Amir. In general, Band-i-Amir weather is strongly continental with low air humidity, high evaporation, wide temperature fluctuations, heavy winter snowfalls, and virtually no summer precipitation. The closest weather station is at Bamiyan town at $2550 \mathrm{~m}$ elevation. Figure 2 represents temperature and precipitation for Bamiyan. Dieterle (1973) presents old weather data from Panjaw and Lal which lie at 2700 and $2800 \mathrm{~m}$ respectively. These data suggest that Band-i-Amir, lying at $2900 \mathrm{~m}$, may be several degrees colder than Bamiyan. Freitag (1971) indicates that Band-i-Amir receives as much as $400 \mathrm{~mm}$ of precipitation per year which is considerably higher than surrounding areas. A large proportion of yearly moisture falls in April and almost none falls during the vegetative growth period. As Larrson (1978) points out, there is a huge difference in the vegetation of the eastern forests (500 $\mathrm{mm}$ precipitation) and Band-i-Amir ( $400 \mathrm{~mm}$ precipitation) simply because the eastern part of the country receives rain during the summer months. 

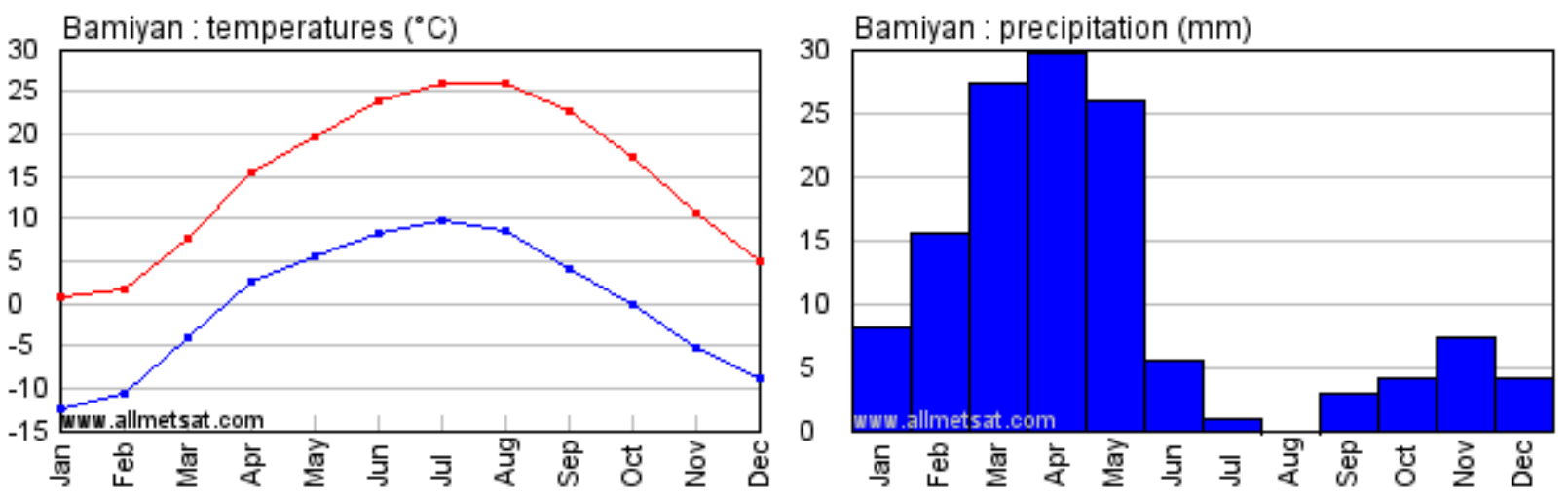

Figure 2. Monthly mean $\max / \min$ temperature and precipitation at Bamiyan. Data from www.allmetsat.com.

On 21 May 2007, a Hobo Pro temperature logger was deployed at Jarukushan. Data were downloaded on October 24. Table 1 summarizes the data collected for June October, 2007.

Table 1. Monthly mean, maximum and minimum temperatures $\left(C^{\circ}\right)$ at Jarukushan during summer 2007.

\begin{tabular}{|l|r|r|r|}
\cline { 2 - 4 } \multicolumn{1}{c|}{} & Average & \multicolumn{1}{l|}{ Max } & \multicolumn{1}{l|}{ Min } \\
\hline June & 17.1 & 33.5 & 4.6 \\
\hline July & 17.9 & 31.4 & 6.2 \\
\hline August & 18.0 & 32.2 & 5.6 \\
\hline September & 13.8 & 29.8 & -2.6 \\
\hline October & 6.9 & 20.8 & -6.9 \\
\hline
\end{tabular}

These data suggest, for summer 2007 at least, that both temperature maximums and minimums are greater at Band-i-Amir than at Bamiyan.

\subsection{Topography and Physiography}

Band-i-Amir lies in a westward extension of the Hindu Kush Mountains just north of the Koh-i-Baba Range. The lakes lie at an altitude of $2900 \mathrm{~m}$ with the surrounding countryside mostly in the range of $3200-3400 \mathrm{~m}$. Mountains in the northern part of the watershed reach almost $3800 \mathrm{~m}$ in height. The land to the south of the lakes is largely an upland plateau which becomes sharply dissected to the east. The area immediately north of the lakes is commanded by Kohe Yak Ruja at $3686 \mathrm{~m}$.

The surface streams and groundwater feeding Band-i-Amir lakes are the headwaters of the Band-i-Amir River which flows west and then north to join the Balkh River. The Balkh River ultimately disappears into the sands north of Mazar-i-Sharif.

Band-i-Amir Lakes are formed by a "staircase" of travertine (precipitated calcite) dams covering approximately $10 \mathrm{~km}$ of the old riverbed of the Band-i-Amir River. Lapparent (1966) recognized 10 numbered Band-i-Amir lakes of which 7 have known names (Figure 3). 
1. Band-i-Jedachel at N34.807, E67.273;

- A shallow alkaline lake in a side valley (Darye Jedachel)

2. A small lake of unknown name in Darye Jedachel not apparent on current mapping;

3. Another small lake of unknown name in Darye Jedachel not apparent on current mapping;

4. Band-i-Zulfiqar centred at N34.840, E67.234

- A large (490ha) and deep (45m) lake

5. Band-i-Pudina at N34.835, E67.201

- A complex of small potholes and lakes with dense vegetation

6. Band-i-Panir at N34.832, E67.208

- A shallow lake on a travertine plateau

7. Band-i-Haibat at N34,826, E67.200

- A large, deep lake with a narrow, steep travertine dam

8. Band-i-Qanbar at N34.820, E67.183

A wet, marshy area with a breached travertine dam

9. Band-i-Gholaman at N34.818, E67.174

- A shallow, reedy lake

10. Large wetland (local name $=$ chel) downstream of Dewkhana-i-Payin centred at $\mathrm{N} 34^{\circ} 813, \mathrm{E} 67.125$

- A completely reed-covered wetland

Several references use incorrect names for the lakes. For example, Jux and Kempf (1971) misnamed Zulfiqar, Haibat, and Pudina. 


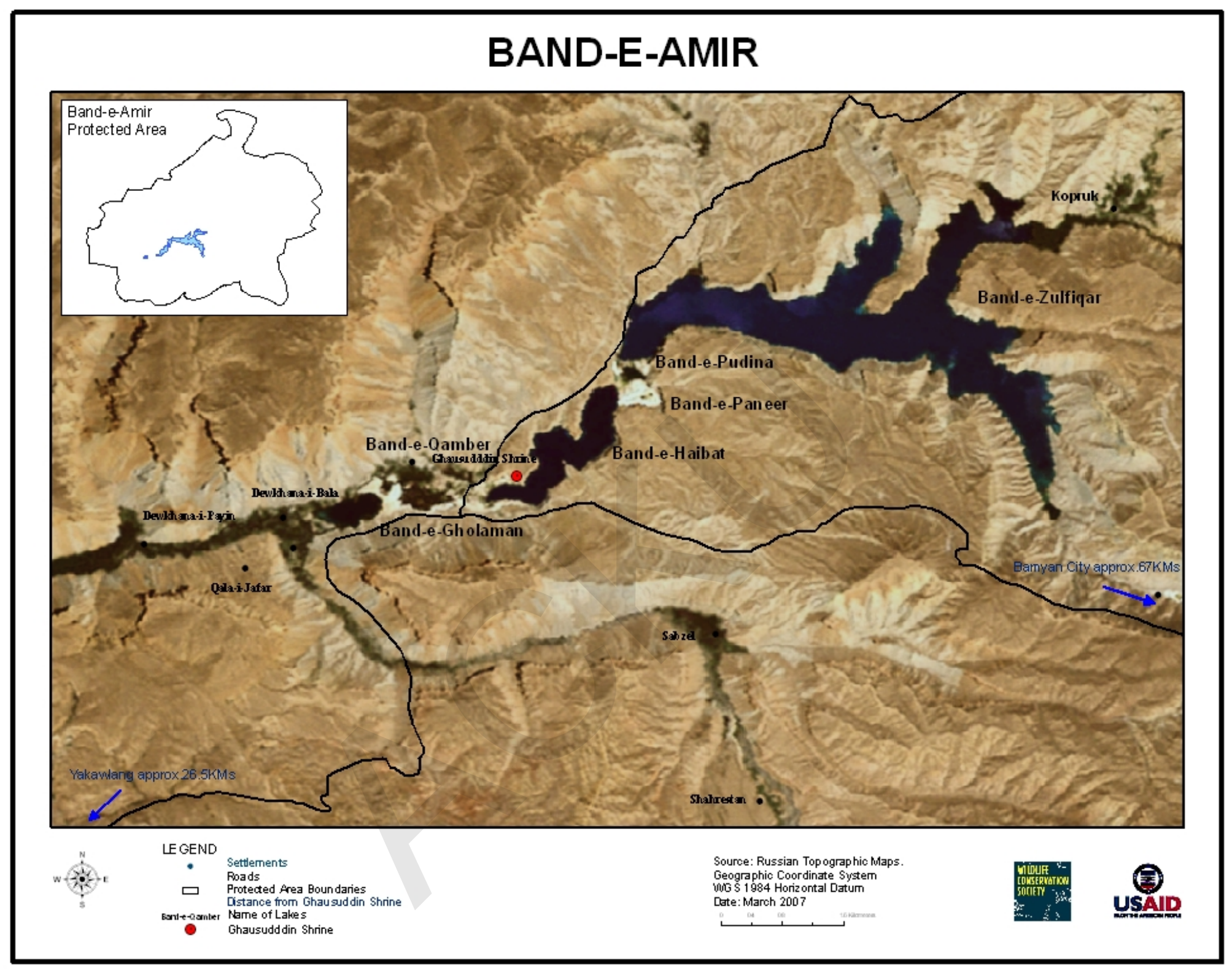

Figure 3. Lakes and towns of Band-i-Amir. 


\section{Geology}

Band-i-Amir lies in an old river valley that has cut down through Cretaceous (144$65 \mathrm{M}$ yr BP) marine limestone deposits and Tertiary (65 - 1.8M yr BP) limestone conglomerates Jux 1975). In geologically recent times, the Band-i-Amir River was captured by the Amu Darya drainage as a result of uplift resulting in the rapid incision of canyons along the Band-i-Amir River as it flows north. Throughout the Quaternary Period (1.8M BP - present), natural travertine dams have been formed and destroyed at Band-i-Amir on at least four occasions (Jux and Kempf 1971, Jux 1975). The remains of these old travertine dams are obvious as cliffs along Band-i-Haibat and Band-iZulfiqar as well as at the village of Dewkhana-i-Payin, downstream of the current lakes. The breakage of the dam at the lower end of Band-i-Qanbar is probably a natural event occurring in the very recent past (ca. 100 years ago). Jux and Kempf (1971) provide a detailed map of surficial geology.

The dams of Band-i-Amir are comprised of the mineral travertine. Travertine is technically defined by Pentecost (2005 p. 3) as:

A chemically-precipitated continental limestone formed around seepages, springs and long streams and rivers, occasionally in lakes and consisting of calcite or aragonite, of low to moderate intercrystalline porosity and often high mouldic (spaces created by secondary dissolution) or framework (spaces created during crystallization) porosity within a vadose (i.e., above the water table) or occasionally shallow phreatic (i.e., groundwater) environment. Precipitation results primarily through the transfer (evasion or invasion) of carbon dioxide from or to a groundwater source leading to calcium carbonate supersaturation with nucleation/crystal growth occurring upon a submerged surface.

Travertine forms when gaseous carbon dioxide from calcium-rich spring water is driven out causing the dissolved calcite $\left(\mathrm{CaCO}_{3}\right)$ to precipitate out, forming the mineral deposits. Travertine sometimes forms in series of terraces or as dams holding back ponds or large lakes. How these unlikely formations might occur has been the source of much scientific discussion. Biological processes appear to influence travertine formation. Eucaryotic algae and cyanobacteria, commonly associated with travertine formations worldwide, reduce $\mathrm{CO}_{2}$ concentrations through photosynthesis facilitating degassing and calcium carbonate deposition. A recent mathematical modelling study has shown that travertine terraces and dams can be explained simply as a result of a depositional instability arising from turbulent flow of a supersaturated solution over a sloping surface (Goldstein et al. 2006).

Travertine also precipitates onto and coats dead and living plant material making it a sort of "living rock" gradually becoming incorporated into the growing travertine deposit. Some studies have shown that this calcite deposition on living and dead plant material reduces the biomass and diversity of aquatic macro invertebrates while others have shown travertine dammed streams to have enhanced decomposition rates, biomass and diversity (Carter and Marks 2007).

\subsection{Soils}

The US Department of Agriculture Natural Resources Conservation Service soil map of Afghanistan (http://soils.usda.gov/use/worldsoils/mapindex/afghanistan-soil.html) shows Band-i-Amir in the zone of "Rocky land with lithic haplocryids". Lithic haplocryids are soils of arid regions with an annual mean temperature of $<8^{\circ}$, considerable lime content, little humus and contact with bedrock within $50 \mathrm{~cm}$ of the soil surface. Jux and Kempf (1971) state that they are grey semi-desert soils with little 
sign of leaching and a $\mathrm{pH}$ of $7.0-7.9$. They are generally $10-30 \mathrm{~cm}$ in depth and rarely deeper than $60 \mathrm{~cm}$ (Jux and Kempf 1971).

\subsection{Hydrology}

The surface waters flowing into Band-i-Amir Lakes have their origins in numerous small streams, many spring-fed, all arising within $20 \mathrm{~km}$ of the west, north and south of the lakes. The lakes are the headwaters of the Band-i-Amir River.

The limestone geology of the Band-i-Amir watershed creates a karst topography. Carbon dioxide dissolved in water creates carbonic acid which dissolves limestone creating underground channels, caves, sinkholes, and springs. The porous ground results in much of the precipitation ending up as groundwater. The surface flow into Band-i-Amir lakes from the surrounding landscape is negligible and most of the water feeding the lake system comes from springs in the lakebeds. There are numerous springs in the area and streams often disappear underground.

Jux and Kempf (1971) measured a maximum depth at Band-i-Zulfiqar of 49m, although there are other, less reliable citations of depths as great as $85 \mathrm{~m}$. In total, the lakes contain about $150 \mathrm{M}$ cubic metres of water (equal to a cube more than $500 \mathrm{~m}$ on each side). The size and average depth of the lakes, as noted in Jux and Kempf (1971 with corrected lake names) are as shown in Table 2. Members of the BAPAC question the validity of the published depth data and consider the lakes to be significantly deeper. A lake depth survey undertaken by local people is planned for summer 2008 .

Table 2. Size, depth and volume of Band-i-Amir lakes.

\begin{tabular}{|l|l|l|l|l|}
\hline & $\begin{array}{l}\text { Lapparant } \\
\text { Number }\end{array}$ & $\begin{array}{l}\text { Size } \\
\left(\mathbf{k m}^{2}\right)\end{array}$ & $\begin{array}{l}\text { Average Depth } \\
(\mathbf{m})\end{array}$ & $\begin{array}{l}\text { Water Volume } \\
\left(\mathbf{m}^{3}\right)\end{array}$ \\
\hline Zulfiqar & 4 & 4.875 & 28 & $136,500,000$ \\
\hline Haibat & 7 & 0.870 & 18 & $15,600,000$ \\
\hline Gholaman & 9 & 0.130 & 2 & 260,000 \\
\hline Jedachel & 1 & 0.050 & 2 & 95,000 \\
\hline $\begin{array}{l}\text { Band-i- } \\
\text { Panir }\end{array}$ & 6 & 0.045 & 1 & 45,000 \\
\hline Unnamed & 2 or 3? & 0.015 & 2 & 30,000 \\
\hline TOTAL & & 5.985 & & $152,530,000$ \\
\hline
\end{tabular}

The water in Band-i-Amir lakes shows a well-defined temperature profile with summer surface temperatures getting as high as $15^{\circ} \mathrm{C}$ and temperatures as low as $3^{\circ} \mathrm{C}$ at depths of $30 \mathrm{~m}$ or greater (Jux and Kempf 1971). Terek (1983) noted bottom temperatures of $5.9^{\circ} \mathrm{C}$ and large differences in water temperature in areas of spring water upwellings. Calcium content varies with depth (Fig. 4 in Jux and Kempf 1971). Terek (1983) found $\mathrm{pH}$ also to decline with depth being 8.2 at the surface, 8.1 at $5 \mathrm{~m}, 7.6$ at $10 \mathrm{~m}, 7.5$ at 15 $\mathrm{m}$, and 7.4 at $20-28 \mathrm{~m}$

Pradhan (2006) did the only full physicochemical analysis on the lake waters, although he did not provide data on depth variations. These data are as shown in Table 3.

Table 3. Physical and chemical properties of waters in Band-i-Amir Lakes (from Pradhan 2006).

\begin{tabular}{|l|l|l|l|l|l|}
\hline Parameters & Gholaman & Haibat & Panir & Pudina & Zulfiqar \\
\hline Water Temperature $\left({ }^{\circ} \mathrm{C}\right)$ & 9.5 & 10.0 & 10.0 & 10.0 & 10.5 \\
\hline Air Temperature $\left({ }^{\circ} \mathrm{C}\right)$ & 15.5 & 16.2 & 16.0 & 16.0 & 14.2 \\
\hline $\mathrm{pH}$ & 7.9 & 8.1 & 8.4 & 8.4 & 8.2 \\
\hline
\end{tabular}




\begin{tabular}{|c|c|c|c|c|c|}
\hline Calcium (mg/l) & 90.0 & 100.0 & 100.0 & 100.0 & 100.0 \\
\hline $\begin{array}{ll}\text { Nitrate } & \mathrm{NO}_{2}-\mathrm{N}(\mathrm{m} \mathrm{g} / 1) \\
& \mathrm{NO}_{2}(\mathrm{~m} \mathrm{~g} / \mathrm{l})\end{array}$ & $\begin{array}{l}<0.1 \\
<0.3\end{array}$ & $\begin{array}{l}<0.1 \\
<0.3\end{array}$ & $\begin{array}{l}<0.1 \\
<0.3\end{array}$ & $\begin{array}{l}<0.1 \\
<0.3\end{array}$ & $\begin{array}{l}<0.1 \\
<0.3\end{array}$ \\
\hline Phosphate (mg/1) & nil & nil & nil & nil & nil \\
\hline Iron $(\mathrm{mg} / \mathrm{l})$ & nil & nil & nil & nil & nil \\
\hline Hardness (mg/l) & 30.0 & 30.0 & 28.0 & 28.0 & 32.0 \\
\hline Dissolved oxygen $(\mathrm{mg} / \mathrm{l})$ & 6.75 & 7.0 & 7.0 & 7.0 & 7.2 \\
\hline Conductivity ( $\mu$ mhos) & 515.0 & 540.0 & 545.0 & 540.0 & 602.0 \\
\hline TDS(mg/l) & 309.0 & 324.0 & 327.0 & 324.0 & 361.0 \\
\hline
\end{tabular}

A better understanding of the hydrology of Band-i-Amir lakes is critical if measures are to be introduced to maintain the quality of the water necessary to maintain the integrity of the travertine dams.

\section{Biological Features}

\subsection{Vegetation}

In the biogeographical floral classification of Takthtijan (1986), Band-i-Amir lies in the Turkestanian Province of the Irano-Turanian Region in the Holarctic Kingdom. The plants of Band-i-Amir are therefore largely European and Central Asian in origin, rather than originating from India and Southeast Asia. According to Freitag (1971), Band-i-Amir lies in the cushion shrubland (Dornpolster-Fluren, Knieholz, Alpine Rasen) natural vegetation region of Afghanistan. Olson et al. (2003) classify the Band-i-Amir region as the GhoratHazarajat Alpine Meadow (PA1004) and consider it as globally "Vulnerable".

The earliest floral study at Band-i-Amir was a short paper by Hayon et al. (1970) concentrating on the plant species of the Band-i-Haibat dam. The major vegetation study at Band-i-Amir was undertaken by Dieterle (1973) which was summarized, and supplemented with further observations, by Shank and Larrson (1977). A recent botanical reconnaissance and ethnobotanical study was undertaken by Ali (2006). For details, the reader is referred to these publications.

Hayon et. al. (1970) conclude that the byrophytes and phanerogams (seed-producing plants) occupying the Haibat dam are typical of the moist mountains of Eurasia. They particularly note the significance of the Olive Beard-moss, Didymodon tophaceus, which forms a dense carpet on the walls of the Haibat dam, particularly in seepage areas. The moss becomes the precipitation substrate for calcite, becoming "petrified" and adding to the accumulation of travertine in the dam walls. The importance of mosses in maintaining the integrity of the dams should be further investigated.

Dieterle (1973) refers to the vegetation of the Band-i-Amir uplands as a pseudoclimax Artemisia - Acantholimon Steppe. He argues that the original vegetation was a grassland dominated by Stipa, Festuca and Hordeum, as is found under similar situations throughout the mountains of Central Asia. This natural vegetation is now completely gone from Band-i-Amir. However, 6 Stipa species and a few Hordeum and Poa species persist as very rare occurrences representing the last remnants of vast grass steppes that once flourished.

The continual removal of grasses by livestock grazing allows the invasion of Artemisia. More intense grazing and uprooting of shrubs for fuel, together with the accompanying soil erosion, promotes invasion of the thorn cushion plants, dwarf shrubs and weeds and the final elimination of grasses. Dryland farming has a similar effect. Today, the 
Band-i-Amir uplands are dominated by species that are either avoided by livestock, (Astragalus, Acantholimon, Acanthophyllum Onobrychis), are spiny (Cousinia, Centauerea), have volatile oils (Salvia, Nepeta), or are poisonous (Euphorbia). The current pseudoclimax vegetation is likely centuries old and is not compatible with both effective animal husbandry and natural values. Recovery of natural range communities should be a long term goal for the conservation area.

Dieterle (1973) notes four plant species as endemic to Band-i-Amir; Jurinea mellophora (Asteraceae), Tiarocarpus neubaueri (Asteraceae), Matthiola cordringtoali (Brassicaceae), and Astragalus dieterlei (Fabaceae). Efforts should be made to locate these species and protect them.

\subsection{Terrestrial Fauna}

The fauna of Band-i-Amir appears to be very impoverished as a result of a long history of land degradation (Shank and Larrson 1977).

Eighty-four species of birds have been recorded at Band-i-Amir, although some of these sightings need to be verified. Evans (1994) lists Band-i-Amir as one of the internationally Important Bird Areas (IBAs) of the Middle East. The BirdLife International website provides more information on the IBA characteristics of Band-iAmir (http:/ / www.birdlife.org/datazone/sites/index.html?action=SitHTMDetails.asp\& $\operatorname{sid}=8007 \& \mathrm{~m}=0$ ). The criteria for listing of Band-i-Amir as an IBA are listed in Table 4.

Table 4. Birds contributing to Band-i-Amir being listed as an internationally Important Bird Area (IBA) by BirdLife International.

\begin{tabular}{|l|l|l|}
\hline Species & Season & Criteria \\
\hline Himalayan Snowcock (Tetraogallus himalayensis) & resident & A3 \\
\hline Lammergeier (Gypaetus barbatus) & resident & B2 \\
\hline Hume's Lark (Calandrella acutirostris) & breeding & A3 \\
\hline Small Whitethroat (Sylvia minula) & passage & B3 \\
\hline Hume's Whitethroat (Sylvia althaea) & passage & B3 \\
\hline Variable Wheatear (Oenanthe picata) & non-breeding & B3 \\
\hline Rufous-tailed Wheatear (Oenanthe xanthoprymna) & non-breeding & B3 \\
\hline White-winged Snowfinch (Montifringilla nivalis) & resident & A3 \\
\hline Afghan Snowfinch (Montifringilla theresae) & resident & A2, A3, B3 \\
\hline Crimson-winged Finch (Rhodopechys sanguineus) & resident & A3, B3 \\
\hline
\end{tabular}

A2 = restricted range species;

A3 = biome restricted species;

B2 $=$ Species with an unfavourable conservation status in the Middle East;

B3 $=$ Species with a favourable conservation status but concentrated in the Middle

East.

Birdlife International also cites the Afghanistan Mountains as a Secondary Endemic Bird Area (EBA) (http://www.birdlife.org/datazone/ ebas/index.html?action= EbaHTMDetails.asp\&sid=372\&m=0). A secondary Endemic Bird Area is an area which supports one or more restricted-range bird species, but does not qualify as a full EBA because fewer than two species are entirely confined to it. The Afghanistan Mountains Secondary EBA is defined by the range of Afghan Snowfinch Montifringilla theresae, which is only known to breed in the mountains of Afghanistan, although there is a nonbreeding record from Turkmenistan. It has been recorded at several scattered localities 
in the mountains of Afghanistan, where it is found on open rocky or grassy slopes and in precipitous mountain valleys at 2,450-3,100 m. Band-i-Amir has been identified as important for conservation of this species (Evans 1994). Local people say that the Afghan Snowfinch is present in winter and is commonly netted. There is no consensus on whether it occurs in the area in summer.

Thirty years ago, local people indicated that ibex and urial still inhabited Kohe Burocinal and Kohe Argosa during the summer months (Shank and Larsson 1977). Local people provided conflicting information on the continuing existence of ungulates in the area. In October 2006, people indicated that they no longer exist in the immediate vicinity, but urial (Ovis orientalis) may exist in Darye Gamow and in the area to the north between Band-i-Amir and the Ajar Valley. In October 2007, there were reports of 26 urial just north of Bala Tang and 13 in Darye Gamow. Red foxes (Vulpes vulpes) and wolves (Canis lupus) are the only known mammalian predators. Wolves commonly prey on domestic livestock, perhaps because natural prey species have been eliminated. Afghan pikas (Ochotona rufescens) are common.

Rodents have not been properly surveyed, but Niethammer (1965) recorded long-tailed marmots (Marmota caudata) and a jerboa (cited as Allactaga williamsi, but probably A. euphratica). In October 2006, Shank (unpubl.) captured an uncertain and possibly unnamed species (William Kilpatrick, pers. com. 2007) of mouse-like hamster (Calomyscus sp.) and the migratory hamster (Cricetelus migratorius). In May 2007, Shank (unpubl.) captured a field mouse tentatively identified as Apodemus pallipes (William Kilpatrick, pers. com. 2007). In summer 2007, a WCS small mammal team trapped almost 50 specimens which have been sent to the Smithsonian Institution for identification. Much more work needs to be done on the small mammals of Band-iAmir.

\subsection{Aquatic Fauna and Flora}

Terek (1983) found pelagic zooplankton to be sparse with most occurring near shore or in isolated pools. Macrozoobenthos was also found to be impoverished and nearly limited to the near shore. The freshwater sponge Ephydatia fluviatilis forms green masses in the littoral shoreline and cascade zones. Terek (1983) provides a list of 37 taxa of zooplankton and 10 of zoobenthos.

Fish appear to be abundant at Band-i-Amir, but they have not been properly surveyed or identified. The predominant fish are loaches (Family Cobitidae) and cyprinids (Family Cyprindae), and the taxonomy of both groups is very difficult and uncertain. The fish fauna of Band-i-Amir is impoverished and may have endemic characteristics.

Terek (1983) cites two species of fish; Schizothoraicthys (i.e., Schizothorax) intermedius, the common marinka, and Noemacheilus (i.e., Triplophysa) stoliczkai, the Tibetan stone loach.

Pradhan (2006) expended considerable effort in angling and gill-netting in Gholaman, Haibat and Zulfiqar. He caught only one species which he considered to be Schizothorax gobioides. S. gobioides was described in the mid-19th century from the Bamiyan River, but the specimens from the type locality have never been re-examined (B. Coad, pers. comm., 2007). Pradhan (2006) noted that local people mentioned the existence sag moi and a foreign species.

In October 2006, Shank (unpubl.) found Capoeta capoeta heratensis, the Transcaucasian barb (locally known as shir moi) and Triplophysa stoliczkai, locally 
known as sag moi. These were both located in the stream below Band-i-Haibat. Shank (unpubl.) was also told of a large, predatory, bottom-dwelling fish locally known as qesillaloi-ragin-kaman or the "foreign fish".

\section{Human Population and Land-Use}

\subsection{Local Population}

There are 15 villages in the area of Band-i-Amir. Table 5 (data provided by BAPAC members, February 2008) indicates the size of the villages, the number of livestock and group representation. In total, there are about 4,775 people living in the Band-i-Amir area. UNEP (2002 unpubl.) found similar numbers of families for Jarukashan, Dewkhana, Qala Jara and Kupruk. Shank and Larsson (1977) estimated 3,000 - 5,000 inhabitants in the mid-1970s (ca. 1354). The numbers of people is somewhat higher than recorded by ADB (2006). However, the numbers of livestock recorded here are substantially higher than reflected in ADB (2006).

Almost the entire population left the Band-i-Amir area at various times during the war. Some left the area entirely while others hid in the hills. Most of the refugees had returned by 2002 but ADB (2005) states that 600 households remained in Iran in 2005. Land tenure and irrigation rights appear to have survived the war intact. Some of the people who left leased their land through the traditional ujura system and recovered their land when they returned.

The people of Band-i-Amir are all Shi'a Muslim. They self-identify themselves as Hazara or Sayyed. The people of the 15 Band-i-Amir villages are $67 \%$ Sayyed and $33 \%$ Hazara (Table 5). Villages tend to be predominantly one or the other. Nomads no longer pass through Band-i-Amir.

Table 5. Villages in the Band-i-Amir area (data provided by BAPAC representatives, February 2008).

\begin{tabular}{|c|c|c|c|c|c|c|c|c|}
\hline \multirow[t]{2}{*}{ Village Name } & \multirow{2}{*}{$\begin{array}{l}\text { Latitude/ } \\
\text { Longitude }\end{array}$} & \multirow{2}{*}{$\begin{array}{l}\text { No. of } \\
\text { Families }\end{array}$} & \multirow{2}{*}{$\begin{array}{l}\begin{array}{l}\text { Pop- } \\
\text { ulation }\end{array} \\
\end{array}$} & \multicolumn{3}{|c|}{ Number of Livestock } & \multicolumn{2}{|c|}{ Group Division } \\
\hline & & & & Sheep & Cattle & $\begin{array}{l}\text { Donkey/ } \\
\text { Horse }\end{array}$ & $\begin{array}{l}\text { Hazara } \\
\text { Non- } \\
\text { Sayyed }\end{array}$ & $\begin{array}{l}\text { Hazara } \\
\text { Sayyed }\end{array}$ \\
\hline $\begin{array}{l}\text { 1. Khakdow/ } \\
\text { Abtugak }\end{array}$ & $\begin{array}{l}\text { N34.953 } \\
\text { E67.259 }\end{array}$ & 65 & 390 & 1625 & 325 & 195 & $92 \%$ & $08 \%$ \\
\hline 2. Abqol & $\begin{array}{l}\text { N34.874 } \\
\text { E67.266 }\end{array}$ & 35 & 210 & 875 & 175 & 105 & $14 \%$ & $86 \%$ \\
\hline 3. Kopruk & $\begin{array}{l}\text { N34.854 } \\
\text { E67.263 }\end{array}$ & 210 & 1260 & 5250 & 1050 & 630 & $05 \%$ & $95 \%$ \\
\hline 4. Koykinak & $\begin{array}{l}\text { N34.769 } \\
\text { E67.233 }\end{array}$ & 50 & 360 & 1500 & 300 & 180 & $100 \%$ & $00 \%$ \\
\hline 5. Sharistan & $\begin{array}{l}\text { N34.784 } \\
\text { E67.223 }\end{array}$ & 45 & 270 & 1125 & 225 & 135 & $89 \%$ & $11 \%$ \\
\hline 6.Sabzil & $\begin{array}{l}\text { N34.803 } \\
\text { E67.217 }\end{array}$ & 55 & 330 & 1375 & 275 & 165 & $00 \%$ & $100 \%$ \\
\hline 7. Jarukashan & $\begin{array}{l}\text { N34.824 } \\
\text { E67.181 }\end{array}$ & 60 & 360 & 1500 & 300 & 180 & $07 \%$ & $93 \%$ \\
\hline 8. Qala Jafar & $\begin{array}{l}\text { N34.812 } \\
\text { E67.161 }\end{array}$ & 60 & 360 & 1500 & 300 & 180 & $17 \%$ & $83 \%$ \\
\hline 9. Dewkhana & $\begin{array}{l}\text { N34.815 } \\
\text { E67.149 } \\
\end{array}$ & 70 & 420 & 1750 & 350 & 210 & $14 \%$ & $86 \%$ \\
\hline $\begin{array}{l}\text { 10. Kotak/ } \\
\text { Naghumak }\end{array}$ & $\begin{array}{l}\text { N34.815 } \\
\text { E67.106 } \\
\end{array}$ & 30 & 180 & 750 & 150 & 90 & $07 \%$ & $93 \%$ \\
\hline $\begin{array}{l}\text { 11. Boghondak } \\
\text { Cheshma }\end{array}$ & $\begin{array}{l}\text { N34.765 } \\
\text { E67.225 }\end{array}$ & 35 & 210 & 875 & 175 & 105 & $100 \%$ & $00 \%$ \\
\hline 12. Sialayak & $\begin{array}{l}\text { N34.774 } \\
\text { E67.179 } \\
\end{array}$ & 20 & 120 & 500 & 100 & 60 & $100 \%$ & $00 \%$ \\
\hline $\begin{array}{l}\text { 13. Gomow and } \\
\text { Dare Buz Gola }\end{array}$ & $\begin{array}{l}\text { N34.802 } \\
\text { E67.077 }\end{array}$ & 50 & 300 & 1250 & 250 & 150 & $20 \%$ & $\mathbf{8 0} \%$ \\
\hline TOTAL & & 795 & 4770 & 19875 & 3975 & 2385 & $33 \%$ & $67 \%$ \\
\hline
\end{tabular}




\subsection{Cultural and Religious History}

The earliest published version of the religious tradition surrounding the creation of Band-i-Amir lakes is related by Burnes (1842) as follows:

"In the time when Balkh, as well as the country now called Hazarajat, was under a Hindoo king called Burbur, (the remains of his imperial city of the same name are still to be seen near Bameean,) he bought a thousand Huzara (slaves), to throw a dam across the river which passed his city of Burbur, which is said to have been fed by 72 streams; but all his dams were carried away. Aly, the son of Aboo Taleeb, called by the Mahomedans Shah i Mardan (the King of Men), was one Friday returning from prayers with his cousin Mahomed, the Arabian Prophet, when he was accosted by a beggar, asking for alms in the name of God; Aly answered he had no money, but requested the beggar to sell him. From this proposal the beggar recoiled with religious horror; but, on Aly insisting, he consented. Aly requested him to place his foot on his, and shut his eyes; in a moment the beggar was transported by the Imam to the city and kingdom of Burbur. The beggar took him before the king for sale, who consented to buy him for his weight in gold provided he would perform three acts: 1. Build a dam over the river; 2. Kill a dragon that infested the country; 3. Bring Aly, the cousin of the Prophet, bound before him. This being agreed to, the beggar bore away the enormous price of his benefactor. Hazrat Aly first applied himself to the construction of the dam. Taking with him the thousand slaves of the king, he examined the spot: the mountain through which the river flowed projected over the river; with one stroke of his sword he made a huge cleft, and with his foot precipitated the mass into the stream so dexterously that every drop of the river was stopped from flowing. The slaves fled in terror to the king, and told him of the miracle that had been wrought. The inhabitants, seeing that Aly had done more than they requested, as he had not only saved the city from floods, but had cut off the irrigation of their lands, entreated him to plan a remedy: this he soon effected by a stroke of his hand, the five fingers making five sluice-gates. He afterwards killed the dragon, by jumping on his stomach; and brought a strip of the back for Burbur, as a trophy. The king asked him then to perform the third agreement: Aly requested the attendants to bind him, and discovered himself to Burbur, who was extremely delighted, of course, as he had for some time been plotting a campaign against the same Aly in his own country. As he was about to order him to be conveyed to prison, Aly burst his chains, and, drawing his sword, called upon them to become converts to the true faith. His sword being, like the shield of Achilles, of immortal workmanship, it soon effected the conversion of Burbur and his people. Taking the beggar with him, he returned to Medina, and arrived there three hours after his departure from that city."

Hackin and Kohzad (1953, pp 11 - 15), Dupree (1977, pp 177 - 178) and Shank and Larsson (1977) all provide essentially the same story, with minor differences. De Planhol (nd) notes a suggestion by Bernard (1978) that Ali's exploits have a wider geographical reference and could be interpreted as an explanatory legend about use of rivers from the Hindu Kush for irrigation. Bourrouilh-Le Jan et al. (2007) provide various versions of the story and relate them to history and geology. The Burnes (1842), Bourrouilh-Le Jan et al. (2007) and Hackin and Kohzad (1953) versions explicitly link Band-i-Amir to the travertine deposits at Dara-i-Ajhdahar (Dragon Valley), located $8 \mathrm{~km}$ southwest of Bamiyan town.

Published information regarding the significance and date of the famous shrine at 'may be translated as "The Place Where Ali Stood" (Qadamjoy = Qadamgah, K.Habibi, pers. comm.) and indicates that is was built "55 years ago", or 1922/1301. Shank and Larsson (1977) state that it was built in 1904/1283. Omrani and Leeming call it the tomb of Aus-ud-Din (i.e., Ghaus-ud-Din, K. Habibi pers. comm.) and indicate it was built in $1844 / 1223$. Hackin and Kohzad indicated a date of $1914 / 1332$. They state that 
the shrine was placed on a location at which Ali left forehead, knee and handprints when he prayed following the creation of the dams.

The citation on the walls above and beside the main entrance reads:

The inscription was written on Saturday the month of Ramadan, the year one thousand three hundred and thirty two of the Hijera year of the prophet, during the reign of the king of the nation and religion, Amir Habibullah Khan. The foundation of this structure was laid by Mohammad Khan, the son of Mohammad Hussain, the representative of government which includes the holy mosque, dome, adjacent rooms and the courtyard. Work on the structure was completed in the month of Shawal. Written by Gul Mohammad Gharnainchi of the Nabat tribe.

This structure was completed with the assistance and supervision of Shah Mirza Hussain Khan, resident of Yak Awlang and Sayed Abdul Ali of Ghazni

The work of Sayed Asadullah Herati and Ustad Qorban Sayed from Gharanjar, Kabul 1332 (Translation by Khushal Habibi, 2007).

This inscription confirms that the structure was built as a mosque in 1914/1332 and was subsequently transformed into a shrine or holy place. Local people seem to agree that it marks the location in which Ali prayed. There is no tomb in the shrine.

The shrine is currently in a poor state of repair. ADB has had a structural assessment undertaken by an international architect who has made recommendations for repair. In fall 2007, local people repaired the holes in the roof with money collected in a donation box. Further repairs should be undertaken as soon as possible.

Women consider bathing in the waters of Band-i-Haibat to confer fertility. Several bathhouses have been built by ACC/UNOPS to allow some degree of privacy.

\subsection{Local Governance}

The traditional governance body for Band-i-Amir communities is the shura, a council of local elders and concerned citizens. In recent years, Community Development Councils (CDCs) have been instituted in most communities largely as an institution to receive development funds from the National Solidarity Program (NSP). CDCs are generally comprised of several communities. Currently, there are $8 \mathrm{CDCs}$ incorporating Band-iAmir communities.

In 2006, a Band-i-Amir Coordinating Council was formed to represent communities in the ADB park planning process. This shura is comprised of 7 communities (Jarukushan, Qala Jafar, Koykanak, Sharestan, Boghondak Cheshma, Kopruk and Khakdow).

In September 2007, the Band-i-Amir Protected Area Committee (BAPAC) was formed to facilitate cooperative government/community management of Band-i-Amir. See Section 8.10.1 for more details on the BAPAC's powers and functions.

\section{4. $\quad$ Living Conditions}

Houses are of traditional mud brick and stone construction with rafter poles bought from outside sources. In the past two years, significant progress has been made in providing electricity to Band-i-Amir communities. NSP provided solar panels for Khakdow and ADB installed solar-powered systems for Jarukashan, Sabzil, Sharistan, 
and half of the homes in Kotak. A hydroelectric project was built by ADB at Dewkhana and provides electricity for Dewkhana and Qala Jafar. A new hydroelectric project proposed by NSP will provide power for Dewkhana, Qala Jafar, Jarukushan and perhaps the shrine area. However, people still depend largely upon uprooted shrubs, field straw, and dung for heating and cooking fuel, although coal use is increasing.

Because of the harsh weather, degraded environment and general poverty, many Bandi-Amir residents live under chronic conditions of fuel scarcity, food insufficiency and economic insecurity.

\subsection{Land Use}

\subsubsection{Irrigated Farmland}

Despite the abundance of water in Band-i-Amir lakes, relatively little is available for irrigation because a) low-lying land tends to be saturated and unsuitable for crops, and b) more favourable uplands generally lie higher than the lake water levels. Irrigated fields lie predominantly above lake levels and are mostly fed from water derived from small surface streams running towards the lakes. Most Band-i-Amir communities choose a mirab to manage and allocate water resources. Irrigated land produces a maximum yield of 30 times what is sown with a 1:10 ratio in the worst years. About half the irrigated land is planted in wheat and barley with the remainder planted in potatoes and fodder. More research needs to be done on the extent and practice of irrigated farming.

\subsubsection{Dryland Farming}

Dryland (i.e., non-irrigated, rain-fed or lalmi) wheat and barley fields are of particular environmental concern because they destroy rangeland, reduce plant diversity, and contribute to soil erosion and loss of soil fertility. Band-i-Amir people understand the significance of allowing lalmi to rest, preferably every other year, but circumstances often do not allow this best practice. In good years, lalmi produces yields of 1: $16-20$ and in bad years 1:8-10. The current extent of lalmi is not known.

Officially, all land outside of villages and irrigated lands belongs to the government. Lalmi land cannot be legally owned, although there are traditional and inheritable rights to use. The local religiously-based custom is that once a farmer plows land, it becomes his to use in perpetuity. Use of lalmi is effectively ignored by the authorities because of the precarious food security of Band-i-Amir people. Lalmi is currently found at altitudes as high as $3300 \mathrm{~m}$. Research needs to be done on the practice and ecological consequences of dryland farming.

\subsubsection{Grazing}

Grazing of livestock is the major economic activity at Band-i-Amir. Table 5 indicates that there are currently around 7,600 sheep and goats, 1,425 cattle and 1,580 horses and donkeys owned by Band-i-Amir residents. Shank and Larsson (1977) reported 10,000 sheep and goats, 1500 cattle, 300 oxen and 200 horses.

As indicated in Section 5.1, millennia of grazing pressure has completely altered natural plant communities. This has significantly reduced the carrying capacity of the land. Healthier and more profitable livestock could be realized if scientific grazing practices were introduced leading to enhanced plant biomass and more palatable plant species. Research needs to be undertaken to determine optimal grazing regimes. Programs should be developed and implemented to make the transition acceptable to local people. 


\subsubsection{Reed cutting}

The reed Phragmites australis (local name = nai) is found along the lakeshores throughout Band-i-Amir, but is concentrated at Band-i-Gholaman and the large wetland between Dewkhana-i-Payin and Kotak (local name $=$ chel). Phragmites is a grass in the Poaceae family and grows to a height of $3 \mathrm{~m}$ at Band-i-Amir. Reeds make excellent habitat for waterfowl and other wildlife. Most accessible reeds are cut in the fall for fuel, fodder and livestock bedding. Communities have established and traditional reed cutting rights to certain lakes. Currently, no community has reed collecting rights at Band-i-Gholiman which explains why reeds often remain on that lake year-round.

\subsubsection{Fuel Collection}

The people of Band-i-Amir depend heavily upon uprooted shrubs and dung for heat and cooking fuel. Fossil fuels (e.g., kerosene, propane, coal) are not affordable by most residents, although an increasing number of wealthier people are using coal from Kahmard for heat. There are very few trees and therefore no fuel wood. Shrubs are used by all residents for bread baking and by most for heating. Shrub collection reduces range biomass, alters plant communities, and increases soil erosion. Dung collection ultimately leads to loss in soil fertility.

\subsubsection{Hunting}

Waterfowl hunting remains a prestigious activity at Band-i-Amir. There are several shooting blinds on the wetland between Dewkhana-i-Payin and Kotak. Other species, such as Rock Doves, are occasionally hunted. BAPAC members report that hunting has decreased substantially since the hiring of Rangers and the introduction of cooperative management concepts.

\subsection{Traditional and Legal Rights}

Current land ownership rights in the Band-i-Amir area, either legal or traditional, are contradictory and poorly understood. In the strictest sense, all lands for which there is no deed of ownership (qawala) belong to the government. Most land at Band-i-Amir falls into this category. However, traditional, sharia-based rights have some level of quasilegal status, including inheritance and leasing rights. Particularly controversial is land ownership near the shrine and lalmi. Communities have traditional land use rights for grazing and reed collection in particular areas. Rights to land use, as opposed to strict land ownership, follow long-held traditions and address issues of grazing, water, and reed-cutting rights.

Much research needs to be undertaken on issues of land ownership and resource use rights in the Band-i-Amir area.

\section{7. $\quad$ Renting Land}

Band-i-Amir residents sometimes rent land use rights for areas under traditional ownership and control. Land uses that may be conferred in this way include grazing, reed cutting, and farming. Land is leased to both local residents and outsiders.

\section{Current Protected Area Status}

\subsection{Tourism}

Since the late 1950s, Band-i-Amir has been a popular visitor destination, so much so that as early as 1970, Habibi (1970 in Shank and Larsson 1977) warned of its overuse 
and "fading natural splendour". Prior to the war, the benefits from tourism were not evenly distributed. The people of Jarukashan owned the land where the hotels and restaurants were situated and rented horses. By contrast, the benefits to the people of Kupruk and other more distant communities was largely limited to providing labour in hotel construction and selling handicrafts or food items to the few international visitors who came to the village on horseback. Residents of these villages indicate that they benefited only minimally from the park.

Tourism was severely curtailed or altogether absent during the unsettled years from 1979 - 2002. The hotel district near Band-i-Haibat was completely destroyed during the Taliban/Northern Alliance fighting in 2001.

Today, Band-i-Amir is once again a popular picnic spot and religious pilgrimage site for Afghan citizens, particularly on Fridays. Numerous expatriate foreigners working in Kabul or elsewhere in the country travel to Band-i-Amir for a short holiday. However, very few international travellers currently visit Afghanistan and Band-i-Amir because of the perceived security situation. The area is little visited during the winter months (November - April) when the lakes freeze over and snow blocks the roads. Most visits are in July and August. A majority of visitors make it a day trip from Bamiyan town and few leave the immediate vicinity of the shrine.

Currently, there are few facilities for visitors at Band-i-Amir. An unauthorized and unsightly bazaar sprang up near the shrine with small shops, a few hotel rooms and several restaurants and tea shops. Land levelling for the hotel cut into a cemetery and human bones were collected and deposited in nearby rock crevices. The bazaar was destroyed by Provincial Government authorities in November 2007.

Several swan-shaped, plastic paddle boats are available for rent. A power boat was previously available for rent, but the motor has been removed under pressure from the Provincial Government. Small, corrugated metal bath houses for women were built by ACC/UNOPS near the shrine and below Haibat dam. Concrete toilets were constructed by the Provincial Reconstruction Team (PRT) below the shrine and over a watercourse on the south side of Band-i-Haibat. Several garbage cans are located in the bazaar, but there is no capacity to remove and dispose of the accumulated trash.

The number of visitors to Band-i-Amir has not been reliably quantified. Unattributed estimates are 30,000 - 40,000 domestic visitors per year and $1000-1500$ foreign sightseers per year (ADB 2006). This number would seem to be high, but does reflect the fact the considerable tourism pressure currently exists.

\subsection{Recent Management Initiatives}

The following management measures at Band-i-Amir have been undertaken between 2003 (1392) and the present, largely by ADB and ACC-UNOPS in cooperation with the national and provincial agriculture departments:

- Design and construction of an entrance kiosk, an administration building and a toilet by ADB;

- Placement of a sign indicating that killing of wildlife is prohibited;

- Installation of a gate, parking lot, and partial restriction of vehicle access to the shrine area;

- Closure to vehicle traffic of the flats on the south side of Band-i-Haibat;

- Hiring five Rangers and one Park Warden;

- Placement of several garbage barrels in the bazaar; 
- Preliminary repairs on the shrine;

- Construction of metal bathing shelters near the shrine and below the Haibat dam by ACC/UNOPS;

- Formation of the Band-i-Amir Protected Area Committee and election of village representatives;

- Removal of bazaar in the shrine area.

\subsection{Current Staffing, Infrastructure and Equipment}

Until recently, there was one employee of the Bamiyan Agriculture Department at Bandi-Amir. In July 2007, the Wildlife Conservation Society funded salaries of four Rangers on an interim basis. However, these Rangers remain poorly equipped. In 2006, ADB employed local people to control vehicle access to the shrine area and ensure parking in the designated area..

There is currently little in the way of infrastructure or equipment at Band-i-Amir. In 2006 - 2007, ADB built an entrance kiosk, an administration/ranger station and a toilet complex, all of which have now been turned over to MoAIL. Two concrete toilets were built by the PRT. Both were inappropriately sited and were removed in December 2007. ACC built corrugated metal shelters for women to bathe in, but BAPAC members say that these are both inadequate and unsightly.

\subsection{Current Threats To the Environment}

The most significant threat to Band-i-Amir is damage to the travertine dams, particularly Band-i-Haibat. Travertine formation is a dynamic and continuous process creating an ever-renewing "living rock". The environmental and chemical conditions supporting such a process are fragile and not well understood at Band-i-Amir.

Water pollution in the source waters of Band-i-Amir and in the lakes themselves is of primary concern. Travertine precipitation depends heavily on the biological processes of algae, bacteria and higher plants. Pollutants that harm these organisms could affect travertine deposition and there the integrity of the dams. Pollution is threatened from a variety of sources:

- Siltation from erosion resulting from overgrazing and intensification of dryland farming;

- Nutrient introduction (particularly phosphorus) from soaps used in bathing, laundry and car washing;

- Increased use of fertilizer and pesticides on agricultural land;

- Disposal of garbage into the lakes by local communities, restaurants, and visitors; and

- Leakage of oil, gas and other pollutants from motorboats.

Mechanical damage to the travertine dams is also a major concern. Large flocks of sheep and goats are often seen in the large, flat expanses of travertine at Band-i-Panir and Band-i-Pudina. Livestock hooves pulverize the soft rock creating a grey powder on the rock surface. People walking along the top of the Haibat dam disrupt the vegetation and have a potential effect on the integrity of the narrow dam.

Uncontrolled tourism represents a threat to Band-i-Amir primarily through the deposition of garbage and uncontrolled vehicle traffic. There are virtually no facilities for garbage disposal at Band-i-Amir. As a result, garbage is a major eyesore at Band-i-Amir and a potential pollution problem. Lack of controls on vehicular traffic and the rapidly increasing number of trucks, vans and cars visiting Band-i-Amir has led to multipletracking of roads and pulverization of travertine. 
Litter not only presents a pollution problem, but also detracts from the scenic values of the area making it less attractive to tourism and represents a visible indicator that basic management is lacking.

\subsection{Perceived Threats to Communities}

BAPAC members have indicated their concern that the management planning process could lead to an erosion of their land use rights, specifically access to grazing, shrub collection, lalmi, and reeds. There is recognition and acceptance that creation of a National Park must entail some land use prohibitions, but worries remain that these restrictions will outweigh benefits arising from the Park.

\subsection{Current Management Constraints}

The primary management constraints are the near complete lack of management capacity. Currently there is:

- Shortage of staff;

- Lack of staff training;

- Little equipment for staff;

- No operational budget;

- No legal status;

- No clearly understood and legally enforceable rules;

- No agreed conservation responsibilities for local people.

This plan is intended to directly or indirectly address each of these constraints.

\subsection{Current Boundaries and Zoning}

There are currently no recognized boundaries for Band-i-Amir. In the 1970s, the boundaries were defined by the Afghan Tourist Organization as a rectangle between $\mathrm{N} 34^{\circ} 45^{\prime}$ to $34^{\circ} 55^{\prime}$ and $\mathrm{E} 67^{\circ} 05^{\prime}$ to $67^{\circ} 20^{\prime}$. However, these boundaries were never officially gazetted and have therefore never had legal status. Shank and Rodenburg (1977) proposed boundaries for Band-i-Amir National Park delineated by the lakes' headwaters. These boundaries were reflected in UNEP's (2003) map of the Park and ADB's (2006) land use plan. ADB (2006) also presented a zoning plan for Band-i-Amir.

\section{Management Prescription}

\subsection{Reserve Justification}

Band-i-Amir is an area of extraordinary natural beauty offset by the starkness of the surrounding countryside. Its natural features are unique in Afghanistan and rare at the global scale. Both Afghans and international travellers journey long distances to recreate at Band-i-Amir and revel in its natural wonders. The economic benefits of tourism offer the opportunity to lift local people out of their current depressed economic situation. Visitors come to Band-i-Amir to experience unspoiled, natural beauty. Therefore, these values must be maintained if local people are to derive economic benefits.

Globally, Band-i-Amir is a superb example of well-developed travertine dams and lakes in a high altitude, arid environment. Travertine systems are found in several places throughout the world. Well-known travertine lake systems include Huang Long Valley (Sichuan, China), Pamukkale (Turkey) and, most famously, Plitvice Lakes National 
Park (Croatia). All of these are on the UNESCO World Heritage List and are major international tourist attractions.

Band-i-Amir is also important to the branding of Afghanistan as an international tourist destination.

\subsubsection{Addressing Objectives of the National Protected Area System}

$\S 42.2 .1$ of the Environment Law states that the justification for any protected area must take into account the objectives of the national protected areas system. The three objectives of the national protected area system are defined in $\S 38$ as:

1. conserve the natural and cultural heritage,

2. preserve present and future sustainable development options by conserving, and where necessary restoring, representative ecosystems, habitats and natural and cultural features and integrating their management into local and national land use plans,

3. ensure the sustainable use of natural resource by involving local communities in all activities related to protected areas, including designating and delimiting areas, developing integrated management plans, and managing protected areas.

The Provisional National Park will conserve the natural heritage by prescribing management actions necessary to protect the travertine dam system and the surrounding environment. This plan calls for full documentation of cultural heritage at Band-i-Amir and for protection of the shrine at Band-i-Haibat.

The Provisional National Park will maintain options for sustainable development by developing strategies for land use in harmony with the environment and offsetting land use impacts by income derived from tourism.

The Provisional National Park will involve local communities through the Protected Area Committee in all matters of Park planning and management as outlined in the Collaborative Management Agreement (Appendix 1) and the Terms of Reference for the Protected Areas Committee.

\subsubsection{Advantages of Band-i-Amir as a Protected Area}

Designation of Band-i-Amir as a Provisional National Park will provide the legal basis for management and protection measures necessary to conserve the travertine dams, pure water, scenic values, and natural environment.

As a legally recognized protected area, Band-i-Amir will ensure that benefits accrue to local people in an organized and effective manner.

Designation as a Provisional National Park will also provide the international recognition essential to marketing of Band-i-Amir, and Afghanistan more broadly, as an attractive tourist destination.

\subsubsection{Disadvantages of Band-i-Amir as a Protected Area}

Conservation measures necessary for protecting Band-i-Amir will necessarily entail restrictions on land use by local people. Such restrictions could range in effect from 
inconvenience to potentially significant hardship. However, such prohibitions and associated penalties will be imposed only following discussion with and advice from communities, will be overseen by the BAPAC which is heavily represented by communities, and will be offset by economic benefits derived from tourism.

The weakest link in the proposed approach is the assumption that international travellers will visit Band-i-Amir and provide significant economic inputs from entry fees and services rendered. Should the current security situation in Afghanistan not improve, international travellers are unlikely to visit Band-i-Amir in significant numbers. The area will likely remain as an important recreational area for Afghan nationals, but they will provide fewer monetary advantages to the Band-i-Amir and its residents.

\subsubsection{The Ecosystem Approach}

The draft Protected Area Regulations define the ecosystem approach as "a strategy for the long-term integrated management of land, water and living resources that places human needs at the center of biodiversity management and promotes conservation and sustainable use in an equitable way." The Protected Area Regulations state that management plans must be based on the ecosystem approach.

The management assumption upon which this management plan is predicated is shown in the following figure:

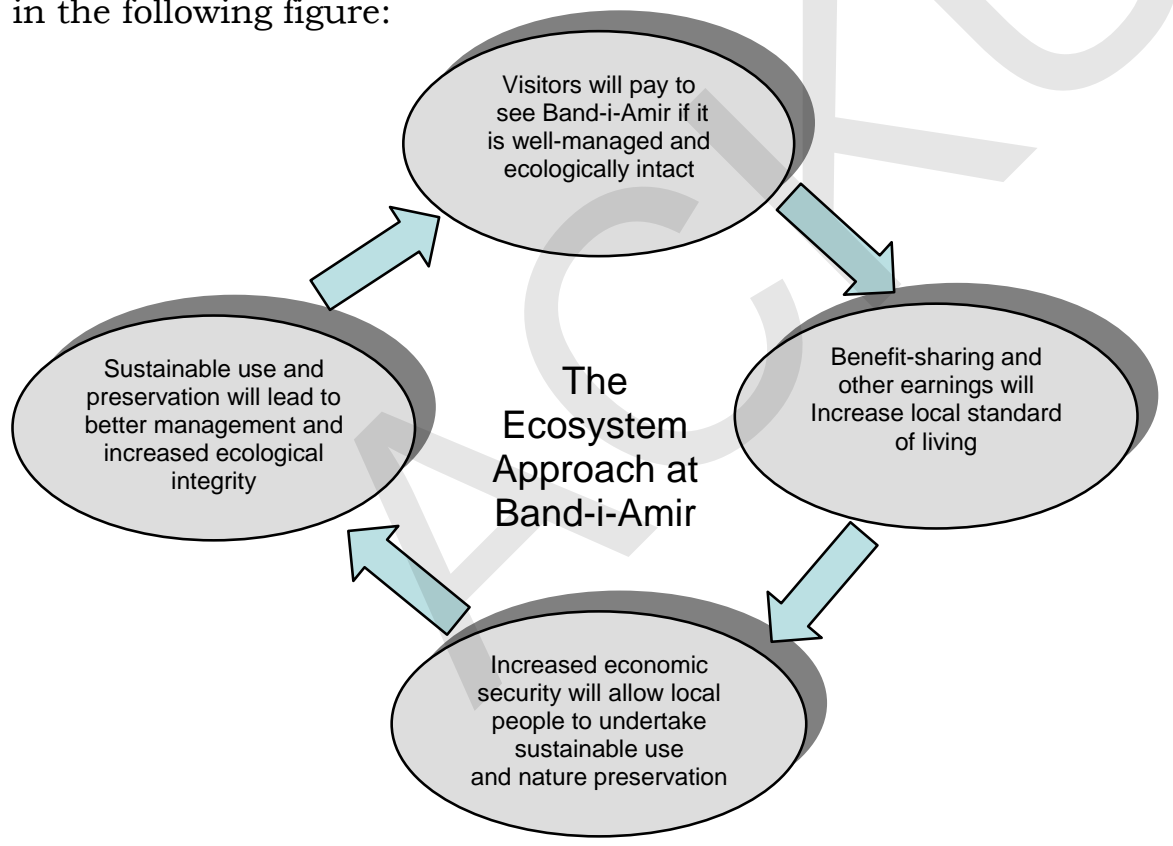

Figure 4. The ecosystem approach at Band-i-Amir.

This cycle illustrates the interdependence of each component of the ecosystem approach. The cycle will be broken if visitors do not come to Band-i-Amir, if local people do not receive economic benefits from tourism, if local people do not alter their land use practices, or if sustainable practices do not lead to intact ecological conditions. Failure to achieve any one of the cycle components jeopardizes chances for success of the National Park. 


\subsubsection{Harmonization with national and provincial approaches}

Currently, national or provincial systems for protected areas have not been developed or implemented. However, this management plan is fully compatible with the protected area section of the Environment Law and the Protected Area Regulations.

\subsection{Community Participation in Planning and Management}

Community participation in planning, development and management of Band-i-Amir National Park will occur at two levels. High level information exchange and decisionmaking will be undertaken by the BAPAC comprised of a majority on this committee. BAPAC representatives are expected to keep their community members informed about Park planning activities. More informal and unstructured discussion and information exchange will be undertaken directly in the communities. Through these two levels of engagement, communities will be informed and will provide input into the final management plan and on-going activities of the National Park.

\subsection{Vision}

The following statement reflects the desired future state of Band-i-Amir National Park:

Vibrant, healthy communities living in harmony with, and engaged in maintaining, an intact lake system, an environment rich in natural beauty, pure water and wildlife that provides high-quality visitor experiences.

\subsection{Long-Term Goals}

The following five broad goals are intended to achieve the vision for Band-i-Amir:

1. Preserve the integrity of Band-i-Amir's travertine dams and lakes;

2. Improve livelihoods in communities near Band-i-Amir;

3. Conserve and recover the biodiversity and ecosystem integrity of Band-iAmir;

4. Provide opportunities for quality recreational, cultural and religious experiences for Afghan citizens and international travellers; and

5. Ensure that local communities are actively engaged in development and management of Band-i-Amir.

\subsection{Objectives; 2008 - 2011}

The following 15 objectives support the five goals and are intended to be achieved by the end of this management plan in 2011 (1390). No priority is indicated by the order in which they are listed. Practical indicators of success should be developed for each by the Warden in consultation with the Protected Area Committee:

1. Fully engage local people in the rights and responsibilities entailed in managing Band-i-Amir's natural heritage;

2. Establish an effectively functioning Protected Area Committee for Band-iAmir;

3. Secure certainty in government funding to MoAIL for management of Band-i-Amir;

4. Establish a fully trained and equipped protected area staff;

5. Undertake effective performance of duties by park staff, including supervision, planning, reporting, monitoring and enforcement;

6. Undertake effective enforcement of the Park prohibitions;

7. Provide a safe and rewarding experience to visitors; 
8. Develop the Amenities Zone in a coordinated manner;

9. Collect fees for entry and concessions;

10. Ensure that communities receive a portion of all fees collected and that funds are responsibly used;

11. Mark the boundary of the Park and the Strict Protection Zones;

12. Undertake research and planning necessary to complete the final management plan;

13. Develop a final management plan based on community participation;

14. Achieve legal recognition of Band-i-Amir National Park by Parliament under the auspices of the Environment Law; and

15. Profile Band-i-Amir nationally and internationally as Afghanistan's model national park.

\subsection{Legal Status}

Under the provisions of the Protected Area Regulations, NEPA should designate, by Executive Order (farman-e-taqneeni), Band-i-Amir as a Provisional National Park by June 2008 (Jauza 1387). This designation should be valid until June 2011 (Jauza 1390), a period of three full years. This designation will provide the National Park with full, but temporary, legal status as a provisional conservation area under the Environment Law.

A full management plan for Band-i-Amir should be completed by Spring 2011 and submitted to Parliament by NEPA for designation as a protected area under $\S 42$ of the Environment Law.

A nomination for Band-i-Amir as a World Heritage Site should be completed and submitted by the Islamic Republic of Afghanistan by 1 February 2009 (11 Hut 1387).

\subsection{Recommended Category of Protected Area}

$\S 40$ of the Environment Law establishes 6 categories of protected area for Afghanistan based on the World Conservation Union (IUCN) categories. These are:

1a and $1 \mathrm{~b}-$ Strict Nature Reserve

II-National Park

III-Natural Monument

IV-- Habitat/Species Management Area

V-Protected Landscape

VI-Managed Resource Protected Area

These categories are described in some detail in IUCN (1994). The summary table (IUCN 1994 , p. 8) below shows how categories of protected areas differ in their management objectives and an assessment of the significance of each at Band-i-Amir.

Table 6. Objectives of different IUCN categories of protected areas (from IUCN 1994).

\begin{tabular}{|l|c|c|c|c|c|c|c|}
\hline Management Objective & Ia & Ib & II & III & IV & V & VI \\
\hline Scientific Research & 1 & 3 & 2 & 2 & 2 & 2 & 3 \\
\hline Wilderness Protection & 2 & 1 & 2 & 3 & 3 & 4 & 2 \\
\hline Preservation of Species and Genetic Diversity & 1 & 2 & 1 & 1 & 1 & 2 & 1 \\
\hline Maintenance of Environmental Services & 2 & 1 & 1 & 4 & 1 & 2 & 1 \\
\hline Protection of Natural/Cultural Features & 4 & 4 & 2 & 1 & 3 & 1 & 3 \\
\hline Tourism and Recreation & 4 & 2 & 1 & 1 & 3 & 1 & 3 \\
\hline
\end{tabular}




\begin{tabular}{|l|c|c|c|c|c|c|c|} 
Education & 4 & 4 & 2 & 2 & 2 & 2 & 3 \\
\hline $\begin{array}{l}\text { Sustainable use of resources from natural } \\
\text { ecosystems }\end{array}$ & 4 & 3 & 3 & 4 & 2 & 2 & 1 \\
\hline Maintenance of Cultural/Traditional Attributes & 4 & 4 & 4 & 4 & 4 & 1 & 2 \\
\hline
\end{tabular}

$1=$ Primary Objective

$2=$ Secondary Objective

3 = Potentially Applicable Objective

$4=$ Less Significant

Of the IUCN Management Objectives, the following are considered to be of primary importance at Band-i-Amir as reflected in the Goals listed in Section 8.4:

- Protection of Natural Features (Goal 1),

- Maintenance of Environmental Services (Goal 1),

- Preservation of Species and Genetic Resources (Goal 3),

- Tourism and Recreation (Goal 4).

Band-i-Amir Goals 2 and 5 are not included in the list of IUCN Management Objectives.

Examination of the table suggests that Band-i-Amir is closest in the classification to Category V (Protected Landscape), Category III (Natural Monument) or Category II (National Park). Band-i-Amir has long been considered to be Afghanistan's first and only National Park. Nothing in the IUCN scheme is antithetical to classification of Band-iAmir as a National Park. The recommendation therefore is that Band-i-Amir be designated, as a Provisional National Park.

\subsection{Boundaries}

For the purposes of this Preliminary Management Plan, the provisional park boundaries are those described in Figure 5. This area is delimited by the upstream watershed of Band-i-Amir Lakes and includes a downstream area encompassing the wetlands extending to Dare Buz Gola in the west.

The primary rationale for this delineation is to allow protection of water resources critical to maintaining the integrity of the lakes, particularly groundwater recharge. Surface flow is a minor source of water to Band-i-Amir and does not contain the calcium carbonate necessary to maintenance and growth of travertine deposits. Most of the water flowing into the Band-i-Amir lakes comes from springs in the lakebeds and is laden with calcium carbonate obtained from the limestone bedrock. The surface watershed is therefore of less significance than the underlying groundwater "watershed". Given that so little is known about groundwater dynamics in the Band-iAmir area, the surface watershed is proposed as the Provisional National Park boundary until such time as hydrogeological information suggests a better delineation.

Park boundaries are based on watershed boundaries and in many cases will not be obvious to local people. Consequently, a boundary marking program is proposed in which markers comprised of blue or yellow painted rocks are located at GPS points every few hundred meters. Red and white paints should be avoided because of their use by mine clearing teams.

These boundaries shall be reviewed by the Protected Area Committee and confirmed or revised in the final management plan. 


\subsection{Zoning}

$\S 22$ of the draft Protected Area Regulations specify that protected areas shall have the following zones:

(1) The conservation zone, the area designated exclusively for the purpose for which the protected area was established;

(2) A strict protection zone, for the protection and management of fragile resources;

(3) The amenities zone, an area in which the visitor center and other facilities required for the management of the protected area may be located; and

(4) A special use zone, an area occupied by human settlement at least five (5) years prior to the declaration of the Provisional Conservation Area or the official establishment of the protected area.

(5) A buffer zone, which is not part of the protected area, outside its boundaries and immediately adjacent to it, shall be designated as an area in which specified development activities are allowed and monitored in order to avoid or minimize harm to the protected area.

The majority of the park area $\left(97 \%\right.$ of $\left.577 \mathrm{~km}^{2}\right)$ is proposed as a "Conservation Zone". In Figure 5, this is represented by all lands within the Park boundary that are not designated as other zones. The purpose of the Conservation Zone is to protect watersheds, maintain landscape scenic values, protect and recover plant and animal species and contribute to the welfare of local people. Initial restrictions in force for the Conservation Zone are noted in Section 8.14 and are expected to be further developed over the next three years in coordination with the Band-i-Amir Protected Area Committee and the local communities.

Three areas are proposed as "Strict Protection Zones" (Figure 6) for the duration of this Preliminary Management Plan:

1. A strip of land $100 \mathrm{~m}$ wide around the entire lake system in which no grazing, building or shrub collection may occur. Reed collection may continue for the duration of this plan. Livestock may enter this zone for watering but must be removed promptly. This protection is necessary to reduce siltation of the lakes during spring runoff. Any irrigated lands within this Strict Protection Zone shall be considered as Special Use Zone for the duration of this plan. The communities of Jarukashan and Kopruk use several traditional areas within the $100 \mathrm{~m}$ zone to overnight livestock. This issue is referred to the BAPAC for resolution.

2. The area between Band-i-Zulfiqar and Band-i-Haibat and containing Band-i-Panir and Band-i-Pudina. This area has critical plant resources and extensive flat deposits of travertine. For a period of three years, livestock will only be allowed to traverse the area expeditiously to cross from one side of the lake system to the other. Grazing of livestock and shrub collection will be prohibited, but reed collection will continue to be permitted. The road leading to the Band-i-Panir dam from the south will be closed to vehicles. The 
BAPAC will decide whether compensation should be paid for trees that were privately planted on the eastern side of Band-i-Panir.

3. The travertine flats bordering Band-i-Haibat and east of the road. This Strict Protection Zone will be closed to vehicles and people will not be allowed to walk on the dam.

Three other areas were considered for designation as Strict Protected Areas, but were removed on advice of the BAPAC. Over the next three years, research and consultation should be undertaken on Band-i-Jedechel, Kaji Isp-i-Aw, and Band-i-Abqol to determine the biological importance of the areas and to better understand human use. If appropriate, they should be designated as Strict Protection Zones in the final management plan.

Two "Amenities Zone" are proposed. The first is located in the shrine area and the valley to the northwest and the area along the cliff face on the north side of Band-iHaibat as far as the Band-i-Zulfiqar dam (Figure 6). This zone does not include the Band-i-Haibat dam or the travertine flats below it which are a Strict Protection Zone. The second is located on the shore of Band-i-Zulfiqar just west of Kopruk (Figure 6). No grazing, new dryland farming or shrub collection will be permitted in the Amenities Zone.

Existing communities and irrigated lands will be designated as "Special Use Zones" (Figure 5) in which no restrictions are placed on land use in this preliminary plan. Special Use Zones shall not expand in size during the period this Preliminary Management Plan remains in effect. A Growth Management Plan will be developed for the final management plan.

Specific cases of hardships caused by these restrictions may be brought before the BAPAC. The BAPAC may amend this management plan as necessary.

Table 7. Areas of Band-i-Amir management zones.

\begin{tabular}{|l|l|c|}
\hline ZONE & AREA $\left(\mathbf{k m}^{2}\right)$ & $\%$ of National Park \\
\hline Conservation Zone & 577.3 & $96.8 \%$ \\
\hline Strict Protection Zone & 3.6 & $0.6 \%$ \\
\hline Amenities Zone & 0.7 & $0.1 \%$ \\
\hline Special Use Zone & 14.9 & $2.5 \%$ \\
\hline TOTAL & 596.5 & $100.0 \%$ \\
\hline Buffer Zone & 655 & \\
\hline
\end{tabular}




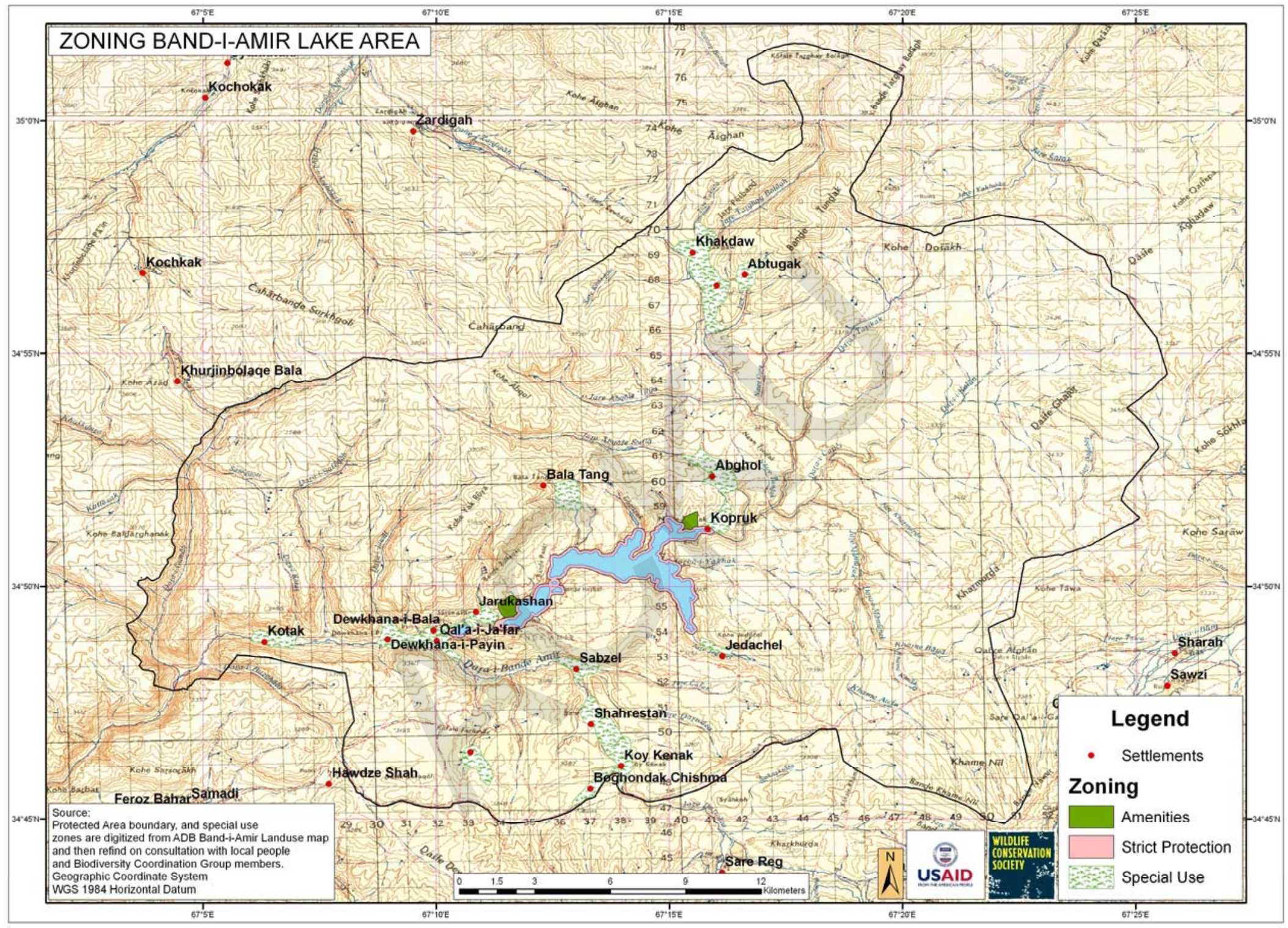

Figure 5. Boundaries and management zones of Band-i-Amir Nationa Park. 


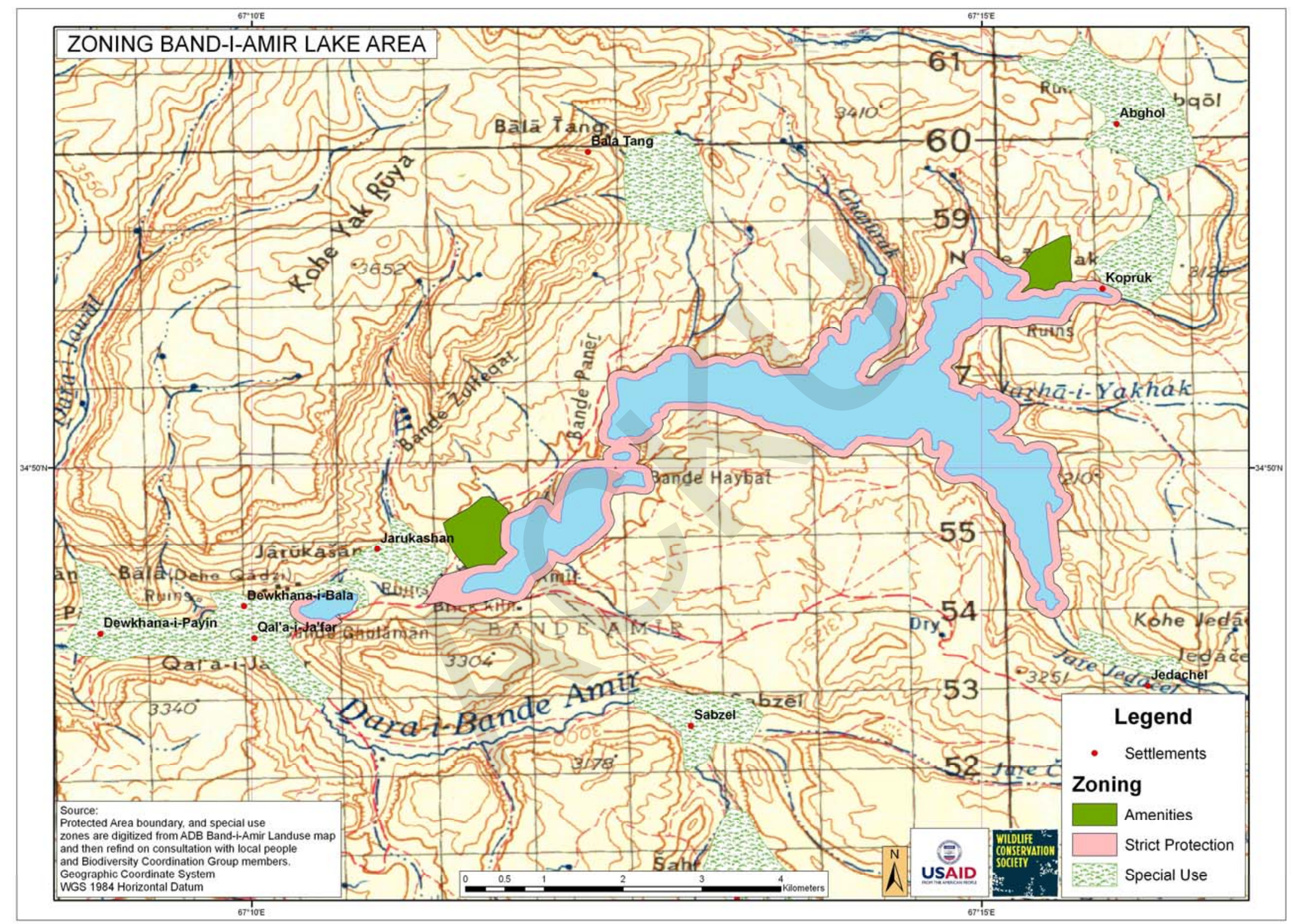

Figure 6. Strict Protection and Amenities Zones around Band-i-Amir Lakes. 
The Protected Area Regulations state that each protected area shall have a Buffer Zone. A Buffer Zone is described as "...an area that is not part of the protected area, outside its boundaries and immediately adjacent to it, shall be designated as an area in which specified development activities are allowed and monitored in order to avoid or minimize harm to the protected area." Buffer Zones may allow a broader range of uses, but are intended to insulate the core from threats to its conservation status. The Buffer Zone will not be marked on the ground.

The primary purposes of the Band-i-Amir Buffer Zones will be wildlife and groundwater protection and to ensure that inappropriate industrial development or resource exploration that might jeopardize Park values does not occur. Until hydrogeological research has been completed, groundwater protection measures in the Buffer Zone cannot be defined.

The interim Buffer Zone for the Provisional National Park shall be a $5 \mathrm{~km}$ wide strip surrounding the park boundaries (Figure 7). This zone encompasses 9 villages. These interim boundaries are acknowledged to be arbitrary at the present time. The boundaries of the Buffer Zone will be examined in detail prior to completion of the final management plan and adjustments made as necessary.

The boundaries of management and Buffer Zones, and their associated prohibitions, should be reviewed by the Protected Area Committee and confirmed or revised in the final management plan.

Table 8 summarizes permitted and restricted activities within each management zone.

\subsection{Authorities}

\subsubsection{Band-i-Amir Protected Area Committee}

$\S 11$ of the draft Protected Area Regulations indicate the required membership on the Protected Area Committee. The Band-i-Amir Protected Area Committee (BAPAC) will be comprised of one representative from each of the following groups:

1. Khakdow/Abtugak

2. Abqol

3. Kopruk

4. Koykinak

5. Sharistan

6. Sabzil

7. Jarukashan

8. Qala Jafar

9. Dewkhana

10. Kotak/Naghomak

11. Boghondak Cheshma

12. Sialayak

13. Gamow/Dare Buz Ghola
14. Governor

15. Representative of the Provincial Council

16. Yakowlang Woleswal, until the District Council is in place

17. NEPA

18. ATO

19. Warden, employee of National Parks and Wildlife Directorate, MoAIL

20. NGOs or private sector, as determined by the BAPAC

The primary roles of the BAPAC are to provide liaison between government and communities, to provide policy guidance to MoAIL on matters of Park management and to administer revenues generated. The primary power of the BAPAC, as set forth under the draft Protected Area Regulations, is to determine penalties to be applied to violations of prohibitions within the range determined by the Minister of Justice. The regulations state that Protected Area Committees shall actively participate in: 
- Preparation of management plans;

- Overseeing implementation of the management plan;

- Updating the management plan as necessary;

- Preparing operational plans and budgets;

- Seeking outside investment for infrastructure;

- Supervising leases, licenses, and permits;

- Managing ecotourism development;

- Providing visitor services;

- Monitoring operational routines, including patrolling;

- Initiating alternative income sources for local communities;

- Monitoring the status of natural and cultural resources;

- Any other function delegated by the MoAIL.

MoAIL remains, by law, the agency responsible for management of protected areas and BAPAC decisions are therefore subject to approval by the Ministry.

\subsection{Programs}

\subsubsection{Resource Management}

\subsubsection{Grazing}

There will be no grazing in the Amenities or Critically Protected Zones. Otherwise, there will be no restrictions on grazing for the duration of this plan $(2008-2011)$. During the lifetime of this plan, research and consultation will be undertaken to determine the long-term grazing regime that best optimizes benefits to local people and the environment.

\subsubsection{Dryland Farming}

For the 3 years in which the Preliminary Management is in effect, there will be no new rain-fed (lalmi) farmland ploughed in the Amenities or Strict Protection Zones.

Established lalmi fields may be farmed. The intent is that the final Management Plan will establish a strategy for the phasing out of all lalmi in the Amenities and Strict Protection Zones. There will be no restrictions on dryland farming in the special use, conservation or Buffer Zones. During the lifetime of this plan, research and consultation will be undertaken to determine an approach to dryland farming that best optimizes benefits to local people and the environment.

\subsubsection{Shrub Collecting}

There will be no shrub collection in the Amenities or Strict Protection Zones. Shrub collecting may be undertaken for fodder or fuel in the Special Use, Conservation and Buffer Zones. No commercial export of shrubs will be permitted. During the lifetime of this plan, research and consultation will be undertaken to determine an approach to shrub collecting that best optimizes benefits to local people and the environment.

\subsubsection{Reed Cutting}

For the 3 year period in which this management plan remains in effect, reed cutting will not be restricted. Research and consultation will be undertaken to determine an approach to reed cutting for inclusion in the final plan that best optimizes benefits to local people and the environment 


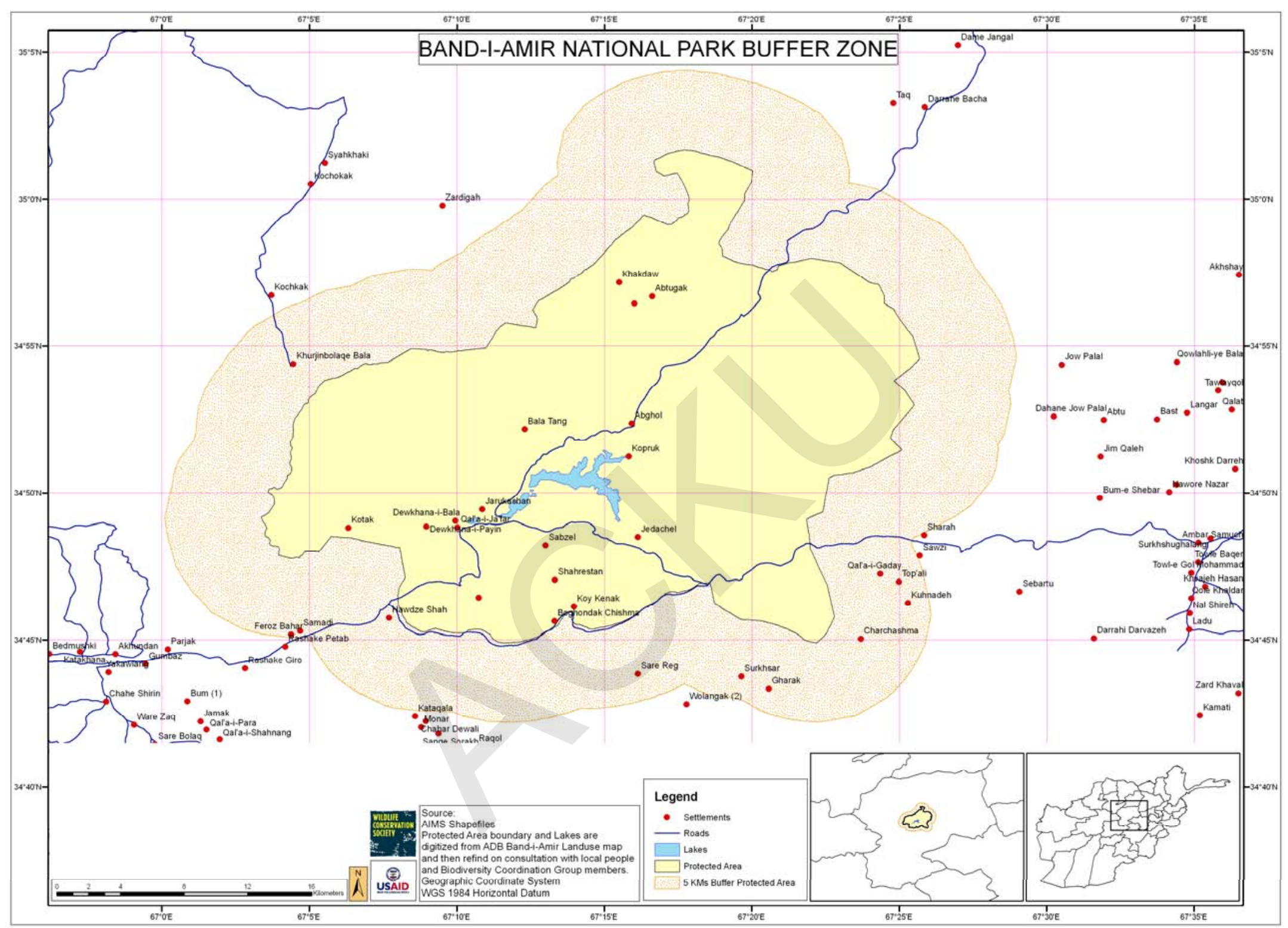

Figure 7. Buffer Zone for Band-i-Amir National Park. 


\subsubsection{Growth Management}

For the duration of this plan, no development will be permitted outside of the Special Use or Amenities Zones and these zones shall not expand in size. Potential growth and methods to address it must be addressed in the full management plan to be completed by 2011 .

\subsubsection{Conservation Awareness}

A program for conveying conservation awareness to local people should be developed and delivered by community liaison officers. This program should emphasize local peoples' responsibility and engagement in conservation.

Until this program can be made operational, conservation NGOs should ensure that local people are generally aware of the principles of protected area management, nature conservation, and sustainable use.

\subsubsection{Visitor Use and Tourism Development}

A detailed facility plan for the amenities zone should be completed by a facilities site planner. This plan should address the following issues:

- Parking and vehicular traffic

- Hotels

- Restaurants and tea shops

- Shops

- Walking trails

- Boardwalks and stairs to protect the travertine around the shrine

- Camping

- Picnicking

- Bathing facilities

- Mosque and washing facilities (uzu)

Some measures have been undertaken to control visitor use and these should be expanded and strengthened immediately. Measures include:

- Charging entrance fees,

- Providing information brochures in English, Dari and Pashto,

- Moving all shops, restaurants and hotels to the valley to the north,

- Providing culturally appropriate picnicking facilities,

- Ensuring that all vehicles park well below the shrine,

- Restricting vehicle access to the southern part of Haibat dam,

- Restricting vehicle access to the top of Band-i-Haibat dam, except by permit,

- Providing litter barrels that are serviced regularly,

- Developing a proper garbage dump,

- Disallowing vehicle washing in the streams.

A tourism development plan should be developed to ensure that tourism at Band-i-Amir is viable and economically rewarding. Among other things, the plan should address commercial advertising, tourism facilities, information products, and tourism training for local people. 


\subsubsection{Facilities and Commercial Operations}

The BAPAC shall determine what commercial facilities and operations will be allowed at Band-i-Amir. The BAPAC, in consultation with the ATO, shall have the authority to issue concessions. The guiding principle shall be that, to the extent possible, commercial enterprises will provide benefits to local people and will be in keeping with the vision and goals of the National Park.

\subsubsection{Research, Monitoring and Planning}

Research needs to be undertaken to provide the information needed to effectively develop the detailed management plan in 2011. All research will be done in coordination with BAPAC, MoAIL, NEPA and affected communities. Research needs and a general description are summarized in the table below:

Table 8. Research needs for Band-i-Amir National Park.

\begin{tabular}{|c|c|}
\hline Research Need & Description \\
\hline Hydrogeological survey & $\begin{array}{l}\text { An expert should review available information on the } \\
\text { hydrogeology of Band-i-Amir and develop the Terms of } \\
\text { Reference and budget for the research project. Funding } \\
\text { should then be sought to undertake this research. }\end{array}$ \\
\hline Range management & $\begin{array}{l}\text { A range expert should examine the nature of the range } \\
\text { resource and its use by local people to recommend a set of } \\
\text { measures to protect the resource and maximize benefits to } \\
\text { local people. }\end{array}$ \\
\hline Dryland farming & $\begin{array}{l}\text { An expert should examine the nature of the dryland farming } \\
\text { and its impacts on the environment to recommend a set of } \\
\text { measures to protect the resource and maximize benefits to } \\
\text { local people. }\end{array}$ \\
\hline Shrub collection & $\begin{array}{l}\text { An expert should examine the nature of the shrub collection } \\
\text { and its impacts on the environment to recommend a set of } \\
\text { measures to protect the resource and maximize benefits to } \\
\text { local people. }\end{array}$ \\
\hline Reed cutting & $\begin{array}{l}\text { An expert should examine the nature of the reed cutting and } \\
\text { its impacts on the environment to recommend a set of } \\
\text { measures to protect the resource and maximize benefits to } \\
\text { local people. }\end{array}$ \\
\hline Traditional land use patterns & $\begin{array}{l}\text { In conjunction with other resource use research, a synthesis } \\
\text { of all temporal and spatial traditional land use should be } \\
\text { developed. }\end{array}$ \\
\hline Cultural and religious places & $\begin{array}{l}\text { A study should be made of culturally and religiously } \\
\text { significant places in the Band-i-Amir area, determine their } \\
\text { location, document oral traditions associated with these } \\
\text { places and make recommendations for preservation of both } \\
\text { tangible and intangible cultural heritage. }\end{array}$ \\
\hline Traditional and legal land rights & $\begin{array}{l}\text { A study should be made of traditional and legal rights to land } \\
\text { tenure and use. }\end{array}$ \\
\hline Tourism & $\begin{array}{l}\text { Entrance statistics should be kept to determine the number } \\
\text { and visitors and the pattern of their use. }\end{array}$ \\
\hline Biophysical inventory & $\begin{array}{l}\text { Cataloguing birds, mammals, fish, plants and aquatic } \\
\text { organisms at Band-i-Amir should continue. Studies of the } \\
\text { dam structures and lake characteristics should be } \\
\text { undertaken. }\end{array}$ \\
\hline
\end{tabular}

\subsection{Environmental Impact Assessment Requirements}

By approving Band-i-Amir as a Provisional National Park, NEPA declares the defined area of Band-i-Amir Provisional National Park and its Buffer Zone as an Environmentally Sensitive Area under §3.1(3) of the Environmental Impact Regulations. All activities within the boundaries of Band-i-Amir Provisional National Park and the Buffer Zone shall be subject to requirements of the Environmental Impact Assessment Regulations. 


\subsection{Declassification}

Declassification of Band-i-Amir as a Provisional National Park shall be done only accordance with the provisions of $\$ 43$ of the Environment Law and the relevant sections of the Environmental Impact Regulations.

\subsection{Prohibitions and Fines}

\subsubsection{Prohibitions listed in the Protected Area Regulations}

The Protected Area Regulations state that the following acts are prohibited in the protected area, unless specially allowed by the management plan. Except where otherwise noted, these prohibitions shall not refer to the Buffer Zone. Specific exceptions are noted indicating where and under what circumstances activities may be undertaken. Exemptions from these prohibitions may be issued in writing by the Warden for specific cases.

$\S 32.3$ of the Protected Area Regulations state that the Ministry of Justice, in consultation with NEPA and MoAIL, shall specify the range of penalties for violation of the Regulations and prohibitions established by this management plan. Appendix III provides recommendations on fines. $\S 11.5 .2$ of the Protected Area Regulations states that the Protected Area Committee has the power to determine the fines within the limits set by the Ministry of Justice.

1. Hunting, collecting, destroying, disturbing, removing, and/or possessing any plant, animal or any part of a plant or animal, or other living or non-living resource;

Specific exemptions:

- Fishing is allowed for subsistence by local residents in all areas except Band-i-Haibat. Capture may only be by hook and line.

- Plants may be collected in all areas except Strict Protection and Amenity Zones by local residents for purposes of subsistence, including fuel, medicine, animal fodder and food. Medicinal and food plants may be sold with the written permission from the Park Warden. Export of shrubs and reeds for sale is expressly forbidden. Predators may be destroyed in the defence of domestic animals only in Special Use Zones and during the act of depredation.

- The Warden may provide written permission for the harvest and possession of any plant or animal.

Note that Presidential Decree, \#53 of 29/12, 1383 currently bans all hunting and trapping in the country and therefore applies equally to the Protected Area and the Buffer Zone.

2. Possessing or setting traps, snares, or any other devices for capturing animals of any kind;

Specific exemptions:

- Snares and traps may be owned and kept only within Special Use Zones. Rodents may be trapped within Special Use Zones.

- The Park Warden may provide written permission to trap pest animals in and outside of Special Use Zones. 
- The Park Warden may provide written permission to trap animals for scientific research.

3. Disposal of waste of any kind on land or in water bodies of any kind;

Specific exemptions:

- Designated dumping areas.

- Although littering is not authorized in the Special Use or Buffer Zones, no fines will be imposed in these areas.

4. Use of motorized equipment, excluding permitted vehicles, of any kind;

Specific exemptions:

- Motorized equipment may be used in Special Use and Facility Zones,

- Vehicles can be used on marked roadways,

- The Park Warden may provide written permission to allow use of motorized equipment in other circumstances.

5. Mutilating, defacing, removing or destroying features of natural and/or cultural value;

Specific exemptions:

- None

6. Damaging roads and trails;

Specific exemptions:

- None

7. Occupying land other than in a designated Special Use Zone;

Specific exemptions:

- Any lands that are claimed as traditional use or legally owned lands, but not included in a current Special Use Zone, may be occupied until the BAPAC has ruled on the issue.

8. Exploration or exploitation of any non-renewable resources;

- None

9. Constructing or maintaining any kind of structure, including fences and enclosures; Specific exemptions:

- No restrictions are made on structures constructed within Special Use Zones,

- Structures constructed in Amenity Zone must first be approved by the BAPAC,

- Structures in the Conservation and Strict Protection Zones may be approved by the BAPAC if they serve the intent of the zoning.

10. Providing any service without an administration contract, lease, license, or permit;

Specific exemptions

- No restrictions are placed on services provided in Special Use Zones.

- This prohibition will not come into effect until the BAPAC has a program in place and specifically activates the prohibition.

11. Altering, removing, destroying or defacing boundary marks or signs and/or any signs or markers placed for management purposes whether outside or in the interior of the protected area.

Specific exemptions

- None 
Items 1,8 and 11 shall apply equally in the Buffer Zone.

\subsubsection{Other Prohibitions}

1. No person shall offer for sale fish procured from lakes or streams within the boundaries of Band-i-Amir National Park.

Specific Exemptions

- With written permission of the Warden, fish may be bought for research purposes.

2. No person shall contravene the specific provisions applicable to management zones. Specific Exemptions:

- None

3. No water wells shall be drilled in Band-i-Amir National Park or the Buffer Zone without the written permission of the BAPAC.

Specific exemptions:

- As determined by the BAPAC.

4. No non-residents may enter the protected area without first paying an entrance fee.

Specific exemptions:

- As determined by the Park Warden.

- This prohibition will come into effect when authorized by the BAPAC.

5. No person shall lease land use (e.g., grazing, reed collecting, crop production) to any person who is not a resident of a Band-i-Amir community. This does not apply to land located within a Special Use Zone.

Specific exemptions:

- With the written permission of the Park Warden

\subsection{Permitted Activities}

All activities not prohibited in the Section 8.14 shall be allowed unless specifically prohibited by the BAPAC.

Table 9 summarizes permitted and restricted activities in each zone.

\section{Table 9. Summary of permitted and restricted activities in Band-i-Amir} management zones.

\begin{tabular}{|l|l|l|l|l|l|l|l|l|l|l|l|l|}
\hline Zone & $\begin{array}{l}\text { Shrub } \\
\text { Collection }\end{array}$ & Grazing & $\begin{array}{l}\text { Reed } \\
\text { Collecting }\end{array}$ & $\begin{array}{l}\text { Dryland } \\
\text { Farming }\end{array}$ & Hunting & Fishing & $\begin{array}{l}\text { Possess- } \\
\text { ing Traps }\end{array}$ & $\begin{array}{l}\text { Waste } \\
\text { Disposal }\end{array}$ & $\begin{array}{l}\text { Motorized } \\
\text { Equipment }\end{array}$ & $\begin{array}{l}\text { Occupy- } \\
\text { ing Land }\end{array}$ & $\begin{array}{l}\text { Construct- } \\
\text { ion }\end{array}$ & $\begin{array}{l}\text { Well } \\
\text { Drilling }\end{array}$ \\
\hline Conservation & YES & YES & YES & YES & NO & YES & NO & NO & NO & NO & NO & NO \\
\hline Special Use & YES & YES & YES & YES & NO & YES & YES & YES & YES & YES & YES & NO \\
\hline Amenities & NO & NO & YES & YES & NO & YES & NO & NO & NO & NO & NO & NO \\
\hline Strict Protection & NO & NO & YES & YES & NO & YES ${ }^{*}$ & NO & NO & NO & NO & NO & NO \\
\hline Buffer & YES & YES & YES & YES & NO & YES & YES & YES & YES & YES & YES & NO \\
\hline
\end{tabular}

${ }^{*}$ Fishing is not permitted in Band-i-Haibat

\subsection{Fees}

Until such time as a revenue sharing agreement is approved by the Ministry of Finance, collection of entry fees shall be at the discretion of the BAPAC. Following approval of the revenue sharing agreement, the following regime shall be implemented: 
People living within the Park boundaries or the Buffer Zone will not be required to pay to enter the Park. Non-Afghan visitors will be charged \$20 (1000 Afghanis). Afghan citizens will be charged 10 Afghanis. Children under 10 years old, both national and international, will not be charged an entry fee. Each person shall be provided with a receipt acknowledging payment of the entry fee and the date. Entry will be valid for multiple consecutive days spent in the Park, but will not be valid for re-entry. The Park Warden may waive entry fees at his discretion; for example, for persons undertaking work on behalf of the Park or school groups. All entries will be recorded for monitoring purposes.

Cars, vans, pickup trucks and buses will be charged a vehicle entry fee of 50 Afghanis. Large trucks will be charged 100 Afghanis. Locally owned vehicles will not be charged. There shall be no charge for parking.

\subsection{Benefit Sharing}

As noted in the Introduction and in Section 8.14, the key to the success of Band-i-Amir National Park is the sharing of economic benefits generated from the park with local residents so their standard of living is enhanced despite potential restrictions on land use.

The Collaborative Management Agreement (Appendix 1) indicates how revenues will be distributed.

\subsection{Resources Required}

The following resourcing recommendations are provided for planning purposes and are not binding on MoAIL or any other party.

\subsubsection{Personnel}

As indicated in the following table, 15 staff will be required to properly staff Band-i-Amir National Park.

Table 10. Staff positions needed for Band-i-Amir National Park.

\begin{tabular}{|c|c|c|c|c|c|}
\hline Title & No. & Duties & Position Type & $\begin{array}{l}\text { Cost/ } \\
\text { person/ } \\
\text { month (Afs) }\end{array}$ & $\begin{array}{l}\text { Annual } \\
\text { Cost (Afs) }\end{array}$ \\
\hline $\begin{array}{l}\text { Warden (PRR } \\
\text { Grade 4) }\end{array}$ & $\mathbf{1}$ & $\begin{array}{l}\text { Overall responsibility for } \\
\text { park management, financing } \\
\text { and policy }\end{array}$ & $\begin{array}{l}\text { Permanent } \\
\text { position }\end{array}$ & $\begin{array}{l}8500 / \mathrm{mo}+ \\
2500 \\
\text { overtime }\end{array}$ & 132,000 \\
\hline $\begin{array}{l}\text { Chief Park Ranger } \\
\text { (PRR Grade 5) }\end{array}$ & 1 & $\begin{array}{l}\text { Overall responsibility of day- } \\
\text { to-day park management }\end{array}$ & $\begin{array}{l}\text { Permanent } \\
\text { position }\end{array}$ & $\begin{array}{l}7800 / \mathrm{mo}+ \\
2300 \\
\text { overtime }\end{array}$ & 121,200 \\
\hline $\begin{array}{l}\text { Administration } \\
\text { and Finance Clerk } \\
\text { (PRR Grade 4) }\end{array}$ & 1 & $\begin{array}{l}\text { Secretarial and accounting } \\
\text { assistance to Park Warden }\end{array}$ & $\begin{array}{l}\text { Local person, } \\
\text { permanent } \\
\text { position }\end{array}$ & $\begin{array}{l}6400 / \mathrm{mo}+ \\
2100 \\
\text { overtime }\end{array}$ & 90,000 \\
\hline $\begin{array}{l}\text { General Staff (Ajir } \\
\text { Grade 3) }\end{array}$ & 5 & $\begin{array}{l}\text { Rangers undertaking } \\
\text { patrolling and enforcement }\end{array}$ & $\begin{array}{l}\text { Local people, } \\
\text { yearly contract }\end{array}$ & $\begin{array}{l}3100 / \mathrm{mo}+ \\
2500 \\
\text { overtime }\end{array}$ & 336,000 \\
\hline $\begin{array}{l}\text { General Staff (Ajir } \\
\text { Grade } 4 \text { or } 5 \text { ) }\end{array}$ & 2 & $\begin{array}{l}\text { Community liaison officers } \\
\text { maintaining community } \\
\text { relations and providing } \\
\text { conservation education }\end{array}$ & $\begin{array}{l}\text { Local people } \\
\text { hired on yearly } \\
\text { contract }\end{array}$ & $\begin{array}{l}2700 / \mathrm{mo}+ \\
2400 \\
\text { overtime }\end{array}$ & 122,400 \\
\hline $\begin{array}{l}\text { General Staff (Ajir } \\
\text { Grade } 4 \text { or } 5 \text { ) }\end{array}$ & 5 & $\begin{array}{l}\text { General tasks, labour, } \\
\text { guarding assets, driving, etc. }\end{array}$ & $\begin{array}{l}\text { Local people } \\
\text { hired on yearly } \\
\text { contract }\end{array}$ & $\begin{array}{l}2700 / \mathrm{mo}+ \\
2400 \\
\text { overtime }\end{array}$ & 306,000 \\
\hline
\end{tabular}


The two senior positions (Park Warden and Chief Park Ranger) should have excellent literacy and personnel management skills and a good understanding of protected area management. The remaining 13 positions would ideally be filled with people from the Band-i-Amir communities or, if necessary, more widely from Bamiyan Province.

\subsubsection{Equipment}

Equipment needed to properly implement Band-i-Amir National Park is noted in Table 11.

Table 11. Equipment list for Band-i-Amir National Park.

\begin{tabular}{|c|c|}
\hline Item & $\begin{array}{l}\text { Initial cost } \\
\text { (Afs) }\end{array}$ \\
\hline 2 pickup trucks & $2,500,00$ \\
\hline 1 satellite telephone & 35,000 \\
\hline 1 Codan radio & 300,000 \\
\hline 12 portable radios & 250,000 \\
\hline 5 motorbikes & 375,000 \\
\hline 5 binoculars & 50,000 \\
\hline 1 spotting scope 8 tripod & 30,000 \\
\hline $\begin{array}{l}1 \text { laptop and } 2 \text { desktop } \\
\text { computers } \& \text { software }\end{array}$ & 150,000 \\
\hline 1 printer & 15,000 \\
\hline 3 UPS units & 15,000 \\
\hline 1 photocopy machine & 100,000 \\
\hline 2 small generators & 50,000 \\
\hline Office furniture & 100,000 \\
\hline Solar electrical system & 250,000 \\
\hline Uniforms and boots & 75,000 \\
\hline Contingency & 50,000 \\
\hline 1 tent & 12,500 \\
\hline 2 first aid kits & 7,500 \\
\hline 2 digital cameras with storage & 50,000 \\
\hline TOTAL & $4,415,000$ \\
\hline
\end{tabular}

\subsubsection{Operational Requirements}

Day-to-day operations of Band-i-Amir National Park will require the resources listed in Table 12.

Table 12. Operational funding (Afghanis) needed to run Band-i-Amir National Park.

\begin{tabular}{|l|l|}
\hline Item & $\begin{array}{l}\text { Annual Cost } \\
\text { (Afs) }\end{array}$ \\
\hline Fuel (trucks, motorcycles and generator) & 150,000 \\
\hline Vehicle Maintenance & 25,000 \\
\hline Facilities Maintenance & 25,000 \\
\hline Stationary and computer equipment & 25,000 \\
\hline Small program implementation & 25,000 \\
\hline Heating and lighting & 25,000 \\
\hline
\end{tabular}




\begin{tabular}{|l|l|}
\hline Contingency & 50,000 \\
\hline TOTAL & 325,000 \\
\hline
\end{tabular}

\subsubsection{Fiscal Requirements}

MoAIL's financial requirements for Band-i-Amir over the next 3 years fiscal years (Nauroz to Nauroz; i.e., March 21 - March 20) are indicated in 13:

Table 13. Total funding requirements (Afghanis) for Band-i-Amir for the next three years.

\begin{tabular}{|l|r|r|r|}
\hline Item & $\begin{array}{l}\text { Year 1387 } \\
\text { (Beginning March } \\
\text { 2008) }\end{array}$ & Year 1388 & Year 1389 \\
\hline $\begin{array}{l}\text { Salaries for Park } \\
\text { Personnel }\end{array}$ & $1,107.600$ & $1,162,950$ & $1,222,100$ \\
\hline Equipment Purchase & $4,415,000$ & 0 & 0 \\
\hline Operations & 325,000 & 340,000 & 355,000 \\
\hline TOTAL & $\mathbf{5 , 8 4 7 , 6 0 0 ~ A f g h a n i s ~}$ & $\mathbf{1 , 5 0 2 , 9 5 0}$ Afghanis & $\mathbf{1 , 5 7 7 , 8 5 0}$ Afghanis \\
\hline
\end{tabular}

Inflation has been factored in at a rate of $5 \%$ annually. It is assumed that infrastructure development, shrine restoration, community development projects, research, and further park planning will all be funded directly by external donors and will not be run through the national park's books. Financial requirements for these projects will be developed by the NGOs in cooperation with the government and communities. Donors might also be approached to provide one-time funding for equipment.

\subsection{Staff Training}

Band-i-Amir National Park staff will require specialized training commensurate with their duties. A staff training plan shall be developed and implemented..

\subsection{Action Plan}

The tasks noted in Table 14 must be completed over the next 3 years. Lead responsibility, initiation date, and completion date is noted for each activity. 
Table 14. Action Plan for implementation of Band-i-Amir National Park over the next 3 years.

\begin{tabular}{|c|c|c|c|c|c|}
\hline & ACTION & $\begin{array}{l}\text { OB- } \\
\text { JECT- } \\
\text { IVE }\end{array}$ & $\begin{array}{l}\text { LEAD } \\
\text { RESPONSIBILITY }\end{array}$ & $\begin{array}{l}\text { INITIA- } \\
\text { TION DATE }\end{array}$ & $\begin{array}{l}\text { COMP- } \\
\text { LETION } \\
\text { DATE }\end{array}$ \\
\hline $\mathbf{1}$ & $\begin{array}{l}\text { Completion of full management plan for } \\
\text { Band-i-Amir }\end{array}$ & 13 & BAPAC/WCS & $\begin{array}{l}\text { Spring } \\
2008\end{array}$ & $\begin{array}{l}\text { Spring } \\
2011\end{array}$ \\
\hline 2 & Submit management plan to Parliament & 14 & NEPA, MOAIL & $\begin{array}{l}\text { Spring } \\
2011 \\
\end{array}$ & $\begin{array}{l}\text { Summer2 } \\
011\end{array}$ \\
\hline 3 & $\begin{array}{l}\text { Ensure human, infrastructure and } \\
\text { financial capacity within MoAIL to } \\
\text { administer Band-i-Amir }\end{array}$ & 3 & MoAIL & $\begin{array}{l}\text { Spring } \\
2008\end{array}$ & On-going \\
\hline 4 & $\begin{array}{l}\text { Ensure BAPAC has sufficient human, } \\
\text { infrastructure and financial capacity }\end{array}$ & 2 & MoAIL & $\begin{array}{l}\text { September } \\
2007\end{array}$ & On-going \\
\hline 5 & Staff hired & 4 & MoAIL & $\begin{array}{l}\text { Summer } \\
2007\end{array}$ & $\begin{array}{r}\text { Summer } \\
2009\end{array}$ \\
\hline 6 & Equipment acquired & 4 & MoAIL & $\begin{array}{l}\text { Spring } \\
2008\end{array}$ & $\begin{array}{l}\text { Septembe } \\
\text { r } 2008\end{array}$ \\
\hline 7 & Park Staff Training & 4 & $\begin{array}{l}\text { WCS/MoAIL/ } \\
\text { NEPA }\end{array}$ & Fall 2007 & On-going \\
\hline 8 & Park staff undertaking duties & 4 & MoAIL & $\begin{array}{l}\text { Summer } \\
2007\end{array}$ & On-going \\
\hline 9 & Institute entrance fee collection & 9 & MoAIL & Uncertain & On-going \\
\hline 10 & $\begin{array}{l}\text { Oversee community distribution and } \\
\text { utilization of funds }\end{array}$ & 10 & BAPAC & Uncertain & On-going \\
\hline 11 & $\begin{array}{l}\text { Conservation awareness program } \\
\text { developed and implemented }\end{array}$ & 1 & $\begin{array}{l}\text { WCS/MoAIL/ } \\
\text { NEPA }\end{array}$ & $\begin{array}{l}\text { Spring } \\
2007\end{array}$ & On-going \\
\hline 12 & Provide priority visitor services & 7 & Unassigned & $\begin{array}{l}\text { Spring } \\
2008 \\
\end{array}$ & On-going \\
\hline 13 & $\begin{array}{l}\text { Complete tourism development plan } \\
\text { and implement as appropriate }\end{array}$ & 7 & $\begin{array}{l}\text { WCS/BAPAC/AK } \\
\text { F/ATO }\end{array}$ & $\begin{array}{l}\text { Summer } \\
2008\end{array}$ & On-going \\
\hline 14 & $\begin{array}{l}\text { Monitor trend in economic security of } \\
\text { local communities (Ecological Goods } \\
\text { and Services) }\end{array}$ & 1 & WCS/BAPAC & $\begin{array}{l}\text { Summer } \\
2008\end{array}$ & On-going \\
\hline 15 & Boundary marking & 11 & $\begin{array}{l}\text { MoAIL/ACC/ } \\
\text { NEPA }\end{array}$ & $\begin{array}{l}\text { Summer } \\
2008\end{array}$ & Fall 2008 \\
\hline 16 & Undertake hydrogeological survey & 12 & WCS/MoAIL & Uncertain & Uncertain \\
\hline 17 & Undertake range management research & 12 & WCS & $\begin{array}{l}\text { Summer } \\
2007\end{array}$ & Uncertain \\
\hline 18 & Undertake dryland farming research & 12 & WCS & $\begin{array}{l}\text { Summer } \\
2007\end{array}$ & Uncertain \\
\hline 19 & Undertake shrub collection research & 12 & WCS & $\begin{array}{l}\text { Summer } \\
2007\end{array}$ & Uncertain \\
\hline 20 & Undertake reed cutting research & 12 & WCS & Uncertain & Uncertain \\
\hline 21 & $\begin{array}{l}\text { Undertake traditional land use patterns } \\
\text { research }\end{array}$ & 12 & Unassigned & Uncertain & Uncertain \\
\hline 22 & $\begin{array}{l}\text { Undertake traditional cultural use } \\
\text { patterns research }\end{array}$ & 12 & Unassigned & Uncertain & Uncertain \\
\hline 23 & Undertake traditional rights research & 12 & Unassigned & Uncertain & Uncertain \\
\hline 24 & Undertake tourism monitoring & 12 & MOAIL/ATO & $\begin{array}{l}\text { Summer } \\
2008\end{array}$ & On-going \\
\hline 25 & Undertake biophysical inventory & 12 & WCS & 2007 & On-going \\
\hline 26 & Complete facilities zone site plan & 7 & BAPAC/WCS & $\begin{array}{l}\text { Spring } \\
2008\end{array}$ & Fall 2008 \\
\hline 27 & Complete repairs on shrine & 7 & BAPAC/others & Uncertain & Uncertain \\
\hline 28 & $\begin{array}{l}\text { Submission of nomination papers for } \\
\text { designation of Band-i-Amir as a World } \\
\text { Heritage Site }\end{array}$ & 15 & WCS & Fall 2008 & $\begin{array}{l}\text { Spring } \\
2009\end{array}$ \\
\hline 29 & Develop Growth Management Plan & 12 & Unassigned & Uncertain & Uncertain \\
\hline
\end{tabular}




\section{References}

ADB 2005. Social development and gender strategy for protected areas in Afghanistan. TA-4541 AFAG: Natural Resources Management and Poverty Reduction. 33 pp.

ADB 2006. Land use plan for proposed Band-e-Amir National Park. TA-4541 AFG: Natural Resources Management and Poverty Reduction. 25pp.

Ali, H. 2006. Floristic and ethnobotanical studies in Band-i-Amer National Park Afghanistan. Asia Development Bank TA-4541(AFG):Natural Resources Management and Poverty Reduction. 41 pp.

Bernard, P. 1978. Ai Khanoum "La Barbare"." E`Tudes De Geographie Historique Sur La Plaine D' Ai Khanoum (Afghanistan). P. Bernard, and H. P. Francfort, Paris.

Bourrouilh-Le Jan, F.G., B. Akram, and M. Schoerer. 2007. Band-e-Amir lakes and Dragon Valley (Bamiyan): myths and seismicity in Afghanistan. In: Piccardi, L. and W.B. Massr (eds.). Myth and Geology. Geological Society, London, Special Publ. 273: 121-132.

Burnes, A. 1842. Cabool: Being a personal narrative of a journey to, and residence in that city, in the years 1836, 7 and 8. 1973 edition. Akademische Druck-u. Verlagsanstalt, Graz, Austria.

Carter, C.D. and J.C. Marks. 2007. Influences of travertine dam formation on leaf litter decomposition and algal accrual. Hydrobiologia 575:329-341.

De Planhol, X. nd. Band-e-Amer. Encylopedia Iranica. http://www.iranica.com/newsite/articles/v3f7/v3f7a004.html

Dieterle, A. 1973. Vegetations kundliche untersuchungen im gebiete von Band-i-Amir (Zentral Afghanistan). Inaug. Diss. Univ. München. 84 pp.

Dupree, L. 2004. Afghanistan. First Indian edition, International Book Service, New Delhi. 776 pp.

Dupree, N. H. 1977. An historical guide to Afghanistan. Afghan Tourist Organization, Publ. No. 5, 2 $2^{\text {nd }}$ ed. 492 pp.

Evans, M.I. 1994. Important bird areas of the Middle East. Birdlife International, Series No. 2. Cambridge, UK. 62 pp.

Freitag H. 1971. Studies in the natural vegetation of Afghanistan. P.H. Davis. Plant life of South-West Asia. Edinburgh: Royal Botanic Garden. p 89-106.

Goldenfeld, N. Chan, P.Y. and J. Veysey. 2006. Dynamics of precipitation pattern formation at geothermal hot springs. Phys. Rev. Lett. 96, 254501.

Habibi, K. 1970. Fading natural splendour of Bande Amir Lakes. Kabul Times, 30 September. 
Hackin, R. and A.A. Kohzad. 1953. Légendes et coutumes Afghanes. Publ. Musée Guimet, Bibliothèque de Diffusion, Vol. LX, Paris.

Hayon, J C., G. Kilbertus, and J. M. Pelt. 1970. Flore et vegetation d'un barrage de travertins en Afghanistan central (Ziarat de Band-I-Amir) (Flora and vegetation of a travertine barrier in central Afghanistan (Ziarat in Band-I-Amir)). Acad. Sci. Compt. Rend. Ser. D. 270, no. 25: 3075-78.

IUCN (1994). Guidelines for Protected Area Categories. CNPPA with assistance from WCMC. IUCN, Gland, Switzerland and Cambridge, UK. X + 261 pp.

Jux. U. 1975. Paläogeographische Entwicklungen an mobilen Schollengrenzen im Westhindukusch (Bande Amir, Zentralafghanistan). Journal International Journal of Earth Sciences. 64, no. 1. 523-540.

Jux, U. and E.K. Kempf. 1971. Staussen durch Travertineabsatz im zentralafghanische Hochgebirge. Z. Geomorph. Suppl. 12 :107-137

Lapparent, A. F. 1966. Les Dépots De Travertines Des Montagnes Afghanes a L'Ouest De Kaboul. Revue De Geographie Physique Et De Geologie Dynamique 8: 351-57.

Larrson, J.Y. 1978. Status of alpine rangelands in Central Afghanistan with special reference to the Ajar Valley Wildlife Reserve. FO:DP/AFG/78/007. Field Document No. 1. $38 \mathrm{pp}+$ map.

Mousavi, S.A. 1998. The Hazaras of Afghanistan: An historical, cultural, economic and political study. Curzon Pr., Surrey.265pp

Olson, D.M. et al. 2001. Terrestrial ecoregions of the world: A new map of life on Earth. BioScience 51(11): 933- 937. See http://www.worldwildlife.org/wildworld/profiles/terrestrial_pa.html

Omrani, B. and M. Leeming. 2005. Afghanistan: A companion and guide. Odyssey Books and Guides.

Pentecost, A. 2005. Travertine. Springer-Verlag. Berlin. 445 pp.

Pradhan, G. B.N. 2006. Assessment on the status of fisheries conservation management and feasibility of fish farming in different areas of Afghanistan. ADB TA 5441(AFG): Natural Resources Management and Poverty Reduction. Kabul. 11 $\mathrm{pp}+$ plates.

Sayer, J. A. and van der Zon, A.P.M. 1981. National Parks and Wildlife Management. Afghanistan. A contribution to a conservation strategy. Vol. 1. UNDP/FAO, Rome.107 pp

Shank, C. C., and J. Y. Larsson. 1977. A Strategy for the Establishment and Development of Band-e-Amir National Park. FAO, FO:DP/AFG/741016.

Takthtajan, A. 1986. Floristic regions of the world. University of California Press, Berkeley and Los Angeles. 522 pp.

Terek, J. 1983. To the knowledge of aquatic fauna of Bandi-Amir Lakes (Afghanistan). Biologia (Bratisl.) 38, no. 2: 167-71. 
UNEP 2003. Afghanistan : Post-conflict environmental assessment. Geneva, Switzerland. 174 pp. Available at

http:// postconflict.unep.ch/afghanistan/report/afghanistanpcajanuary2003.pdf 


\section{Appendix 1. Collaborative Management Agreement: Band-I-Amir Provisional Conservation Area}

THIS AGREEMENT (herein Agreement) is made and entered into this _ day of 13 , between the following parties authorized to enter into this Agreement as representatives and on behalf of the Central Management Authority pursuant to $\$ 21.1$ of the Protected Areas Regulation (herein Regulation):

Chairperson of the Band-i-Amir Protected Areas

Committee (herein Committee),

WARDEN of the Band-I-Amir Provisional Conservation Area (herein Conservation Area), an employee of the Ministry of Agriculture, Irrigation and Livestock, and

a Community RePResentative as appointed by the Committee and acting on behalf of the communities identified by the Band-I-Amir Interim Management Plan (herein Management Plan).

This agreement shall remain in effect for the 3-year duration of the Provisional Management Plan.

\section{RESOURCE UsE RIGHTS AND RESPONSIBILITIES}

1. Communities that are parties to this Agreement as represented by the Community Representative, shall have rights and responsibilities for resources in the Conservation Area as follows:

a. Revenue Sharing: Pursuant to the Protected Area Regulations, all revenues earmarked for communities shall be divided at the following rates on a schedule decided by the Committee, but at a minimum once per year.

\begin{tabular}{|r|l|r|}
\hline & $\begin{array}{l}\text { Khakdow } \\
\text { and }\end{array}$ & \\
1 & Abtugak & $8 \%$ \\
\hline 2 & Abqol & $7 \%$ \\
\hline 3 & Kopruk & $13 \%$ \\
\hline 4 & Koykanak & $7 \%$ \\
\hline 5 & Sharistan & $7 \%$ \\
\hline 6 & Sabzil & $8 \%$ \\
\hline 7 & Jarukahsan & $13 \%$ \\
\hline 8 & Qala Jafar & $8 \%$ \\
\hline 9 & Dewkhana & $9 \%$ \\
\hline 10 & Kotak & $5 \%$ \\
\hline & Boghdonak & \\
11 & Cheshma & $5 \%$ \\
\hline 12 & Sialyak & $5 \%$ \\
\hline & Gomow and & \\
13 & Buz Gola & $5 \%$ \\
\hline
\end{tabular}


b. Community Conservation Funds: Revenues received and distributed pursuant to the Protected Areas Regulation and §1(a) of this Agreement shall be held in a Community Conservation Fund with the group or institution selected by the local community and approved by the Committee. Such group may include the Community Development Council, District Shura, or other person, group, or organization.

c. Expenditures: Local communities shall have the right to expend community conservation funds to improve community livelihoods and conserve natural resources of the Conservation Area. Decisions to expend funds shall be decided by the group or organization selected by the local community for such decisions. In no event, shall the holder of the funds make such decisions. A record of all decisions shall be maintained.

d. Accounting: Local communities shall report on the use of community conservation funds to the Committee on a schedule to be approved by the Committee, but at a minimum on an annual basis. Such reports shall include the record of decisions, an itemized list of all expenditures, and a description of the work completed or activities performed.

e. Grazing Rights: For the duration of this Agreement or until amended by the Band-i-Amir Protected Area Committee, community members may graze animals according to tradition on all lands designated as Special Use, Conservation or Buffer Zones. Grazing in Amenities Zones and Strict Protection Zones shall be restricted according to the terms of the Provisional Management Plan.

f. Rainfed Farming (Lalmi): Community members shall have the right to farm in rainfed lands pursuant to terms and conditions contained in the Management Plan. No new lalmi may be ploughed in any Strict Protection Zone or Amenities Zone as defined in the Provisional Management Plan. Fines for contravention of these provisions shall be as cited in the Provisional Management Plan.

g. Hunting and Trapping: Pursuant to Presidential Decree, \#53 of 29/12, 1383, no hunting or trapping shall be permitted. When such Decree is lifted, hunting and trapping may only occur pursuant to the terms of the Management Plan. Fines for contravention of these provisions shall be as cited in the Provisional Management Plan.

h. Fishing: As described in the Provisional Management Plan, community members shall have the right to fish only for personal consumption and only with hook and line. Fishing in Band-i-Haibat is prohibited.

i. Tourism: Community members shall have the right to engage in tourism activities pursuant to the terms and conditions contained in the Management Plan. The Committee may set and collect concession fees for tourism businesses operating in the Conservation Area.

j. Entrance Fees: Residents of designated Band-i-Amir communities shall not be subject to Park entrance fees for the duration of this agreement. Such communities shall be designated by the Committee and approved pursuant to a $75 \%$ majority.

k. Community Boundaries: Special use lands, as shown in Provisional Management Plan, shall be available for use by local community members within the terms of this Agreement, Management Plan, and all laws and regulations governing them. Special use lands may not be expanded during the period of this Agreement. 
1. Enforcement of Agreement and Management Plan: Community members shall have the responsibility to observe the terms of this Agreement and the Provisional Management Plan and to cooperate with the Warden in the enforcement of such. They shall have the right to present claims involving intracommunity disputes under this Agreement and Plan to the Committee.

m. Designating Community Representatives for the Committee. Each community represented on the Committee shall keep a record of its designation of a representative. Such record shall be submitted to the Committee in written or testimonial form, to be recorded by the Committee, and shall be effective from the date of submission.

n. Changing Community Representatives on the Committee. Any community may change its representative at any time for any reason by submitting a new record of designation as required in §3(a) of this Agreement. The changing of a representative shall not render invalid decisions made by such representative prior to their removal. Once removed, no former representative may act in a representative capacity for purposes of this Agreement unless and until reinstated by their respective community.

o. Rights of Community Representatives on the Committee. Representatives shall have full authority to act on behalf of their community or organization, including voting for changes to the terms of this Agreement or the Management Plan.

1. The WARDEN, in addition to the powers and functions enumerated in the Regulation, shall have the following rights and responsibilities for resource management in the Conservation Area:

p. Third Party Authorizations: The Warden shall exercise due diligence and cooperate in obtaining any third party authorizations, including government permissions, necessary to implement this Agreement or any amendments hereto.

q. Consultation: The Warden shall consult with local communities on a regular basis for the continuing and appropriate management of resources.

r. Local Development: Consistent with the management plan, the Warden shall assist local communities with plans and activities for the improvement of livelihood opportunities.

s. Local Staff: When exercising his or her authority under the Regulation, the Warden shall hire local people as staff for the Conservation Area where appropriate local skills exist.

t. Auditing of Community Conservation Funds: The Warden may audit expenditures of Community Conservation Funds and inspect projects and activities funded by such.

u. Enforcement: Enforce laws, regulations, rules, this Agreement, and Management Plan governing the Conservation Area against any individual acting in contravention of such.

2. The Protected Area Commitee, in addition to the powers and functions enumerated in the Regulation, shall have the following rights and responsibilities for management in the Conservation Area:

v. Delegations of Authority: The Committee shall have the right to delegate rights and responsibilities for the implementation of specific projects to groups created 
by the Committee or to groups already existing but not otherwise a party to this Agreement.

w. Inter-Community Disputes: As a function of the enforcement sub-committee established pursuant to the Regulation, hear disputes between members of different communities related to any rights or responsibilities contained in the laws, regulation, management plan or agreement governing the Conservation Area;

x. Auditing of Community Conservation Funds: The Committee, or individual or group delegated authority by the Committee, shall have the right to audit the records and uses of any Community Conservation Fund at its discretion.

y. Protected Area Committee Funds: Revenues received for operations of the Committee pursuant to the Regulation shall be held by a group or institution selected by the Committee and approved by the Central Management Authority.

z. Expenditures: The Committee shall have the right to expend such funds for Committee operations, to improve community livelihoods, and conserve natural resources of the Conservation Area. Decisions to expend funds shall be decided by the Committee pursuant to $\S 6$ of this Agreement.

aa. Accounting: The Committee shall report on the use of Committee funds to the local communities and the Central Management Authority on a schedule to be approved by the Central Management Authority, but at a minimum on an annual basis. Such reports shall include the record of decisions, an itemized list of all expenditures, and a description of the work completed or activities performed.

\section{OTHER TERMS AND CONDITIONS}

3. Governing Law and Incorporation of Other Documents: This Agreement is subject to the laws and regulations of Afghanistan and incorporates the terms of the Band-I-Amir Provisional Management Plan. A violation by any party of the terms of any governing law or the Management Plan shall constitute a violation of this Agreement.

4. Decision-Making. Decisions related to the implementation of any activity pursuant to the Band-I-Amir Management Plan or this Agreement shall be taken by a majority of representatives present at any meeting where a quorum of at least $51 \%$ of all representatives is present unless otherwise stated in the Regulations, Management Plan, or Internal Arrangements. Decisions shall be recorded in writing by the Protected Area Committee.

bb. Amendments. Amendments to the CMA shall be valid upon a vote of $2 / 3$ of the parties and a quorum of $80 \%$. Amendments shall be in writing only, attached to and incorporated herein by this reference. Decisions to amend shall be taken within 2 weeks of the event requiring amendment or submission of the item requesting amendment to the Protected Area Committee.

cc. Optional Amendments. The Parties may amend this Agreement at any time to reflect the desires of the parties provided such amendments comply with the laws and management plan governing the Band-I-Amir Provisional Conservation Area.

dd. Required Amendments. The Parties shall amend this Agreement to reflect any changes caused by 1) changes in Band-I-Amir boundaries, 2) changes in the legal status of the Band-I-Amir area, and 3) changes in land or resource uses caused by other events or legislation. 
5. Assertion of Claims. Any party wishing to submit a claim under this Agreement shall provide written notice to all other parties within a reasonable time from the event or events giving rise to the claim, but in no instance greater than one year. Claims concerning disputes between members of the same community shall be submitted to the local Shura according to custom and tradition. Claims concerning disputes between members of different communities shall be submitted to the Committee. Claims concerning disputes between a community member and an individual or other legal entity shall be submitted to the appropriate body for resolution.

The Parties have hereunto set their hands and seals this day of , 13

(signature and/or seal)

(typed name)

as the duly appointed ChaIRPERson of the Protected Area Committee

(signature and/or seal)

(typed name)

as the WARDEN of the Band-I-Amir Provisional Conservation Area

(signature and/or seal)

(typed name)

as the Community RePResentative of the communities of the Band-I-Amir Provisional Conservation Area 


\section{Appendix 2. Rules of Procedure, Band-i-Amir Coordinating Committee}

In accordance with the Protected Areas Regulation (herein Regulations) and the laws of the Islamic Republic of Afghanistan, the following Rules of Procedure have been approved by the Band-i-Amir Protected Area Committee (herein BAPAC) to govern the Committee's internal affairs and decision-making

\section{General Purposes.}

The purposes for which the BAPAC is formed, and the powers which it may exercise, are set forth in the Regulations, the Collaboration Management Agreement (herein CMA) required by the Regulations, and these Rules of Procedure. All provisions, including actions taken under these provisions, which are inconsistent with these purposes and powers shall be prohibited.

\section{Name and Location}

The name of this Protected Area Committee is The Band-i-Amir Protected Area Committee. The principal place of operation shall be Band-i-Amir and such other places as the BAPAC may determine.

\section{Fiscal Year}

The fiscal year of the BAPAC shall begin the first day of Hamal each year.

\section{Membership and Records}

Membership in the BAPAC shall be governed by the Regulations, the CMA, and these Rules of Procedure. A record of membership and all changes to it shall be kept by the Secretary of the BAPAC.

\section{Election of Community Members}

1. The election of community members to the BAPAC shall be conducted through a secret ballot supervised and validated by the Ministry of Agriculture and NEPA.

2. All community residents 18 years of older are eligible to vote and to nominate or be nominated persons for the election.

3. The date, time, and positions to be voted on shall be announced to all community members at least one week prior to the intended date of the elections.

4. Elected members shall have a term of 2 years.

\section{Appointment of Government Members}

Government members shall be appointed by their respective agencies pursuant to the rules and procedures governing such appointments. 


\section{Meetings}

The BAPAC shall meet a minimum of four times per year. The dates shall be set by the voting members. Additional meetings of the members may be called for any purpose at any time by the vote of the majority of a quorum of the members.

\section{Notice and Place of Meetings}

All BAPAC members and communities represented on the BAPAC must be notified prior to holding meetings and given enough time to attend.

\section{Quorum}

The presence in person at any meeting of $51 \%$ of voting members of the BAPAC shall constitute a quorum for any action except as otherwise provided in these Rules of Procedure.

\section{Open Meetings}

Observers may attend any and all meetings at the discretion of the chair. Observers may be removed from a meeting as deemed appropriate by the chair.

\section{Voting Requirements}

All actions taken by the BAPAC shall require a vote of a simple majority of the quorum present, unless otherwise stated in the Regulations, the Collaborative Management Agreement, or these Rules of Procedure.

\section{Voting Members}

All BAPAC members may vote. At all meetings of members, each member may vote in person or by proxy. All proxies must be approved by the Chairman and may only be exercised for the meeting where presented.

\section{Special Appointments}

The voting members may elect such other officers as the affairs of the BAPAC may require, each of whom shall hold office for such period, have such authority, and perform such duties as the voting members may, from time to time, determine.

\section{Resignation and Removal}

Any officer may be removed from office by a majority of the voting members with cause. Any officer may resign at any time.

\section{Expulsion and Suspension}

A member may be expelled or suspended by a seventy-five percent (75\%) majority vote of a quorum of the BAPAC. The effect of expulsion or suspension shall extend only to the individual member. The BAPAC may reinstate a suspended or expelled member at any time upon seventy-five $(75 \%)$ majority approval of a quorum of the BAPAC. An expelled or suspended member shall automatically be reinstated at the end of the expulsion or suspension period. No vote of the BAPAC shall be required for such reinstatement. 


\section{Prohibited Acts}

The Officers shall not take any of the following actions, without the vote or written consent of a seventy-five percent $(75 \%)$ majority of the voting members of the BAPAC:

(a) Enter into a contract with a third person wherein the third person will furnish goods or services for the BAPAC or the protected area for a term longer than one (1) year.

(b) Compensate Officers or members of the BAPAC for services performed in the conduct of the BAPAC's business provided, however, that the Officers may cause an Officer or a member to be reimbursed for expenses incurred in carrying on the business of the BAPAC.

\section{Action Taken Without a Meeting}

No action shall be taken without a meeting.

\section{Inspection of Records}

The membership register, books of account and minutes of meetings of the members and of committees shall be made available for inspection and copying by any member of the BAPAC, or the member's duly appointed representative, at any reasonable time and for any purpose.

\section{Amendments}

These Internal Arrangements may be amended at any meeting of the members by a vote (in person or by proxy) of a majority of the members of the BAPAC. However, the percentage of voting power necessary to amend a specific clause or provision shall not be less than the prescribed or affirmative votes required for action to be taken under that specific clause.

\section{Conflict of Governing Laws}

In the case of any conflict between the Regulations, Collaborative Management Agreement, and these Internal Arrangements, the Regulations shall control. In case the Regulations, CMA, or Internal Arrangements conflict with the provisions of Afghan law, the provisions of that law shall control. 


\section{Signature Page}

We, the undersigned, being all of the voting members of Band-i-Amir Protected Area Committee, do hereby certify that we assent to the within and foregoing Rules of Procedure and hereby adopt the same.

IN WITNESS WHEREOF, we have hereunto subscribed our names this the day of 13

(signature and/or seal)

(typed name)

as the duly appointed ChaIRPERson of the Protected Area Committee

(signature and/or seal)

(typed name)

as the WARDEN of the Band-I-Amir Provisional Conservation Area

(signature and/or seal)

(typed name)

as the Community RePResentative of the communities of the Band-I-Amir Provisional Conservation Area 


\section{Appendix 3. Recommendations to the Ministry of Justice on Penalties for Violation of the Regulations and Prohibitions}

1. Hunting, collecting, destroying, disturbing, removing, and/or possessing any plant, animal or any part of a plant or animal, or other living or non-living resource;

Recommended Fines

- Illegal hunting shall entail a fine of 100 - 10,000 Afghanis for Afghan citizens or $5000-500,000$ Afghanis for non-Afghans. The BAPAC will determine the size of the fine based on the specific circumstances.

- At the BAPAC meeting held 23 September 2007, the following fines were determined for illegal fishing:

o Afghans fishing with a net-up to 5000 Afghanis on the first offence and 10,000 Afghanis on the second and subsequent offences.

o Afghans fishing with a basket-up to 500 Afghanis.

o Afghans fishing with hook and line in Band-i-Haibat-up to 100 Afghanis.

- Illegal export of shrubs will entail confiscation of the cargo and a fine of up to 5000 Afghanis per truckload from the seller.

- Illegal export of reeds will entail confiscation of the cargo and a fine of up to 150 Afghanis per donkey-load from the seller.

2. Possessing or setting traps, snares, or any other devices for capturing animals of any kind; Recommended Fines:

- Possession and use of traps, snares, fishnets or other devices for capture of wild animals or fish entails a fine of up to 500 Afghanis for Afghan citizens or up to 5000 Afghanis for non-Afghans and forfeiture of the capture device.

3. Disposal of waste of any kind on land or in water bodies of any kind;

Recommended Fines

- Contravention will entail a fine of 10 - 500 Afghanis.

4. Use of motorized equipment, excluding permitted vehicles, of any kind;

Recommended Fines:

- Contravention will entail a fine of up to 1000 Afghanis.

5. Mutilating, defacing, removing or destroying features of natural and/or cultural value;

Recommended Fines

- Contravention will entail a fine of up to 1000 Afghanis.

6. Damaging roads and trails;

Recommended Fines

- Contravention will entail a fine commensurate with Afghan Ghanun Jaza.

7. Occupying land other than in a designated Special Use Zone;

Recommended Fines: 
- Contravention will entail a fine of 500 - 10,000 Afghanis. The BAPAC will determine the size of the fine based on the specific circumstances.

8. Exploration or exploitation of any non-renewable resources;

Recommended Fines

- Penalties shall be up to up to 500,000 Afghanis as determined by the Minister of Agriculture, Irrigation and Livestock.

9. Constructing or maintaining any kind of structure, including fences and enclosures; Recommended Fines

- Penalties shall be 10,000 - 30,000 Afghanis as determined by the BAPAC.

10. Providing any service without an administration contract, lease, license, or permit; Recommended Fines

- Fines shall be as determined by the BAPAC.

11. Altering, removing, destroying or defacing boundary marks or signs and/or any signs or markers placed for management purposes whether outside or in the interior of the protected area.

Recommended Fines

- Contravention shall entail a fine of up to 500 Afghanis.

\section{Other Prohibitions}

1. No person shall offer for sale fish procured from lakes or streams within the boundaries of Band-i-Amir National Park.

Recommended Fines

- Contravention shall entail a fine of up to 500 Afghanis.

2. No person shall contravene the specific provisions applicable to management zones. Recommended Fines

- Contravention shall entail a fine of up to 500 Afghanis.

- Ploughing new lalmi in an Amenities or Strict Protection Zone shall entail a fine of up to 10,000 Afghanis.

3. No water wells shall be drilled in Band-i-Amir National Park or the Buffer Zone without the written permission of the BAPAC.

Recommended Fines

- Contravention will entail a fine of up to 10,000 Afghanis.

4. No non-residents may enter the protected area without first paying an entrance fee.

Recommended Fines:

- Contravention shall entail a fine of up to 200 Afghanis for Afghans and up to 2500 Afghanis for non-Afghans.

5. No person shall lease land use (e.g., grazing, reed collecting, crop production) to any person who is not a resident of a Band-i-Amir community. This does not apply to land located within a Special Use Zone.

Recommended Fines

- Up to 10,000 Afghanis, as determined by the BAPAC. 